\title{
Electronic Tuning of Arylnickel(II) Complexes by Para Substitution of the Terdentate Monoanionic 2,6-Bis[(dimethylamino)methyl]phenyl Ligand
}

\author{
Lucia A. van de Kuil, ${ }^{\dagger, \ddagger}$ Henri Luitjes, ${ }^{\ddagger}$ David M. Grove, ${ }^{\dagger}$ Jan W. Zwikker, $\ddagger$ \\ Johannes G. M. van der Linden, $\$$ Annie M. Roelofsen,,$^{\S}$ Leonardus W. Jenneskens, $\ddagger$ \\ Wiendelt Drenth, ${ }^{\ddagger}$ and Gerard van Koten ${ }^{*}, \dagger$ \\ Department of Metal-Mediated Synthesis and Department of Physical Organic Chemistry, \\ Debye Institute, Utrecht University, Padualaan 8, $3584 \mathrm{CH}$ Utrecht, The Netherlands, and \\ Department of Inorganic Chemistry, University of Nijmegen, Toernooiveld, \\ 6525 ED Nijmegen, The Netherlands
}

Received September 2, $1993^{\star}$

\begin{abstract}
Aryl bromides of the type $\mathrm{BrC}_{6} \mathrm{H}_{2}\left(\mathrm{CH}_{2} \mathrm{NMe}_{2}\right)_{2}-2,6-\mathrm{R}-4\left(\mathrm{R}=\mathrm{NH}_{2}, \mathrm{MeO}, \mathrm{H}, \mathrm{Cl}, \mathrm{MeC}(\mathrm{O})\right.$ ) have been synthesized and have been used to prepare the corresponding organonickel(II) complexes $\left[\mathrm{Ni}\left\{\mathrm{C}_{6} \mathrm{H}_{2}\left(\mathrm{CH}_{2} \mathrm{NMe}_{2}\right)_{2}-2,6-\mathrm{R}-4\right\} \mathrm{Br}\right]$ by an oxidative addition reaction to $\mathrm{Ni}^{\circ}(\mathrm{COD})_{2}(\mathrm{COD}=$ cycloocta-1,5-diene). The effect that the para substituent of the monoanionic, $N, C, N^{\prime}$ terdentate, aryl ligand has on the electronic properties of the nickel complexes has been investigated by ${ }^{13} \mathrm{C}$ NMR and UV/vis spectroscopy as well as by electrochemistry. The results show that para substitution on the aryl ligand markedly influences the nickel(II) center; electron-donating substituents increase the ease of oxidation to $\mathrm{Ni}{ }^{\mathrm{III}}$, and direct correlations exist between chemical shift data for the carbon atom bonded to nickel and appropriate Hammett parameters.
\end{abstract}

\section{Introduction}

Many multidentate ligands have been developed to control the coordination sphere of the nickel triad metals. Terdentate ligands in particular impose special restrictions on metal complex geometry, which can have important chemical consequences. During recent years our research has been focused on the chemistry of organometallic complexes which contain the monoanionic, terdentate ligand $\left[\mathrm{C}_{6} \mathrm{H}_{3}\left(\mathrm{CH}_{2} \mathrm{NMe}_{2}\right)_{2}-2,6\right]-(\mathrm{NCN})$. It can adopt a variety of binding modes to late-transition metals, not only as a six-electron donor but also as a four- and twoelectron donor. ${ }^{1}$ This ligand has provided a rich, unique, chemistry that has included the isolation of oxidative addition intermediates, viz. a diiodine molecule $\eta^{1}$-bonded to $\mathrm{PtII}^{2}$ unusual isomerization of the NCN system in iridium species, ${ }^{3}$ and most relevant here, a family of stable organonickel(III) species. ${ }^{4}$

In the square-planar nickel(II) complexes of this ligand the metal center is bonded via a direct $\mathrm{M}-\mathrm{C}_{\text {aryl }} \sigma$-bond and the two ortho tertiary amino substituents are chelatebonded to the metal center in a mutually trans fashion (see for example 2a in Figure 1). ${ }^{5}$ In contrast, the organonickel(III) derivatives $\left[\mathrm{Ni}\left\{\mathrm{C}_{6} \mathrm{H}_{3}\left(\mathrm{CH}_{2} \mathrm{NMe}_{2}\right)_{2}-2,6\right\} \mathrm{X}_{2}\right]$

* To whom correspondence should be addressed.

+ Department of Metal-Mediated Synthesis.

Department of Physical Organic Chemistry.

Department of Inorganic Chemistry.

- Abstract published in Advance ACS Abstracts, December 1, 1993.

(1) van Koten, G. Pure Appl. Chem. 1989, 61, 1681.

(2) van Beek, J. A. M.; van Koten, G.; Smeets, W. J. J.; Spek, A. L. J. Am. Chem. Soc. 1986, 108, 5010.

(3) van der Zeijden, A. A. H.; van Koten, G.; Luijk, R.; Nordemann, R. A.; Spek, A. L. Organometallics 1988, 7, 1549.

(4) Grove, D. M. van Koten, G. Mul, P. Zoet, R. van der Linden, J. G. M.; Legters, J.; Schmitz, J. E. J.; Murall, N. W.; Welch, A. J. Inorg Chem. 1988, 27, 2466.

(5) (a) Grove, D. M.; van Koten, G.; Ubbels, H. J. C.; Zoet, R.; Spek, A. L. Organometallics 1984, 3,1003. (b) van Beek, J. A. M.; van Koten, G.; Ramp, M. J.; Coenjaarts, N. C.; Grove, D. M.; Goubitz, K.; Zoutberg, M. C.; Stam, C. H.; Smeets, W. J. J.; Spek, A. L. Inorg. Chem. 1991, 30, 3059 .
( $\mathrm{X}=$ halide) have square-pyramidal structures. 4 During these earlier investigations it was found that the organonickel(II) complexes [ $\left.\left.\mathrm{Ni}_{2} \mathrm{C}_{6} \mathrm{H}_{3}\left(\mathrm{CH}_{2} \mathrm{NMe}_{2}\right)_{2}-2,6\right\} \mathrm{X}\right]$ have remarkably low $\mathrm{Ni}{ }^{\mathrm{II}} / \mathrm{Ni}$ III redox potentials, ${ }^{4}$ and this prompted a study of their catalytic properties in the Kharasch addition reaction, ${ }^{6}$ i.e. the $1: 1$ addition of polyhalogenated alkanes, such as $\mathrm{CCl}_{4}$ or $\mathrm{CF}_{3} \mathrm{CCl}_{3}$, to alkenes with the formation of new $\mathrm{C}-\mathrm{C}$ and $\mathrm{C}-\mathrm{X}$ bonds (see eq 1 ). ${ }^{7}$

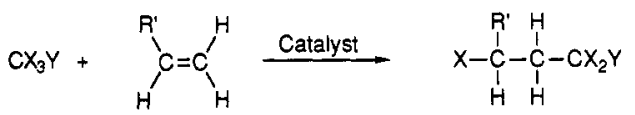

$X=$ halogen; $Y=H_{1}$ halogen, $C F_{3}$ or other electronegative group

An important aspect of the NCN ligand is that it offers several possibilities for modification whereby one can tune the reactivity of the complexed metal center. One of the possibilities that has already been considered for the organonickel(II) species was the substitution of one $\mathrm{Me}$ group on the $\mathrm{NMe}_{2}$ unit, i.e. the use of $\mathrm{NMeR}^{\prime}$ units. ${ }^{5 b}$ In the series where $\mathrm{R}^{\prime}$ is variously $\mathrm{Me}, \mathrm{Et}, i-\mathrm{Pr}$, and $t-\mathrm{Bu}$, we found that the catalytic activity dropped with increasing bulk of this nitrogen substituent.

Here we consider a second possibility, namely the introduction of substituents in the para position of the

(6) (a) Kharasch, M. S.; Jensen, E. V.; Urry, W. H. Science 1945, 102, 169. (b) Asscher, M.; Vofsi, D. J. Chem. Soc. B 1968, 947. (c) Orochov A.; Asscher, M.; Vofsi, D. J. Chem. Soc. Perkin 2 1973, 1000 . (d) Matsumoto, H.; Nakano, T.; Nagai, Y. Tetrahedron Lett. 1973, 51, 5147. (e) Matsumoto, H.; Nakano, T.; Takasu, K.; Nagai, Y.J. Org. Chem. 1978, 43, 1743. (f) Susuki, T.; Tsuji, J. J. Org. Chem. 1970, 35, 2982. (g) Tsuji, J.; Sato, K.; Nagashima, H. Tetrahedron 1985, 43, 393. (h) Davis, R.; Groves, I. F. J. Chem. Soc., Dalton Trans. 1982, 2281. (i) Davis, R.; Durrant, J. M. A.; Khazal, N. M. S.; Bitterwolf, T. E. J. Organomet, Chem. 1990, 386, 229. (j) Hajek, M.; Silhavy, P.; Malek, J. Collect. Czech. Chem. Commun. 1980, 45, 3488. (k) Vit, Z.; Hajek, M. Collect. Czech. Chem. Commun. 1987, 52, 1280. (l) Bellus, D. Pure Appl. Chem. 1985, 57, 1827. (m) Nondek, L.; Li Gwang Hun; Wichterlová, B.; Krupicka, S. J. Mol. Catal. 1987, 42, 51.

(7) (a) Grove, D. M.; van Koten, G.; Verschuuren, A. H. M. J. Mol. Catal. 1988, 45, 169. (b) Grove, D. M.; Verschuuren, A. H. M.; van Koten, G.; van Beek, J. A. M J. Organomet. Chem. 1989, 372, C1. 


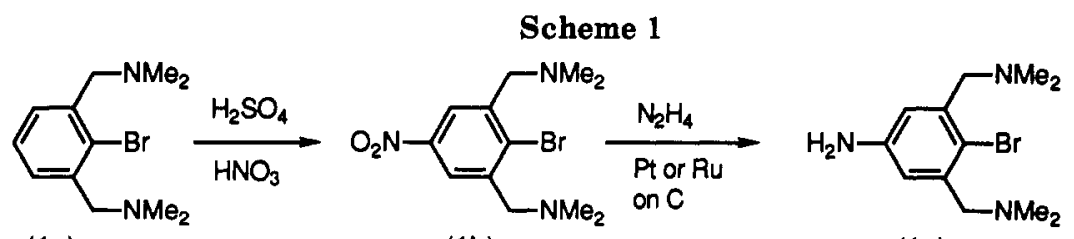

(1a)

(1b) (1c)

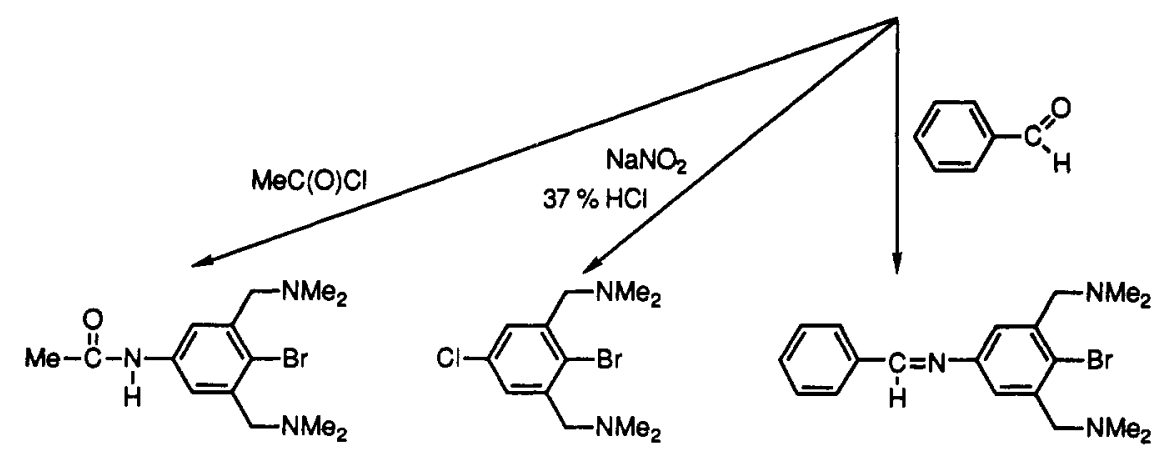

(1d)

(1e)

(1f)

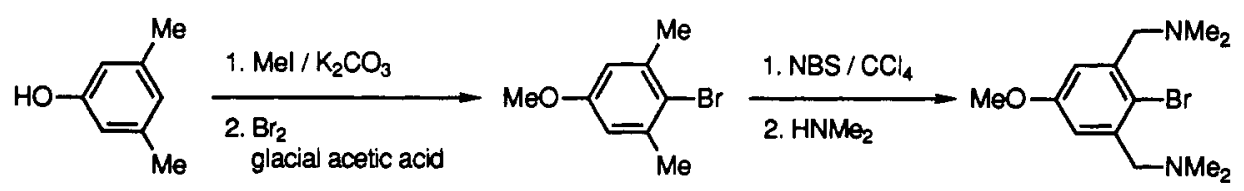

(19)

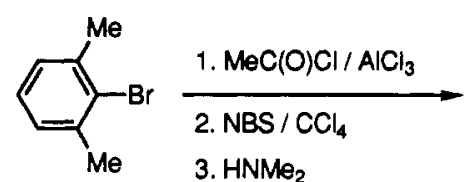<smiles>CC(=O)c1cc(CN(C)C)c(Br)c(CN(C)C)c1</smiles>

(1h)<smiles>[R]c1cc2c(c([N+](C)(Br)Br)c1)CN(C)CN2C</smiles>

$R=H$ $\mathrm{NO}_{2}$ $\mathrm{NH}_{2}$ $\mathrm{MeC}(\mathrm{O}) \mathrm{N}(\mathrm{H})$ (2a) $\mathrm{Cl}$

(2b) $\quad \mathrm{PhCH}=\mathrm{N}$

(2c) $\mathrm{MeO}$

$\mathrm{MeC}(\mathrm{O})$ (2e)

(2f)

(2g)

(2h)
Figure 1. Schematic structure of complexes $\left[\mathrm{Ni}^{\mathrm{II}}\left\{\mathrm{C}_{6} \mathrm{H}_{2}\left(\mathrm{CH}_{2-}\right.\right.\right.$ $\left.\left.\mathrm{NMe}_{2}\right)_{2}-2,6-\mathrm{R}-4\right\} \mathrm{Br}$ ], $\mathbf{2 a}-\mathbf{h}$.

aryl ring to form the ligand $\left[\mathrm{C}_{6} \mathrm{H}_{2}\left(\mathrm{CH}_{2} \mathrm{NMe}_{2}\right)_{2}-2,6-\mathrm{R}-4\right]^{-}$ ( $p$-RNCN). It is to be anticipated that through their mesomeric or inductive effects the $R$ substituents will affect the properties of organonickel(II) complexes of these ligands and thus their catalytic ability in the Kharasch addition. ${ }^{8}$ Detailed knowledge about the effects of para substituents on the catalytic properties of such nickel complexes is also appropriate in view of our current studies of modified nickel complex catalysts based on NCN, that are anchored to a support via a spacer that connects $\mathrm{C}_{\text {para }}$ to the supporting backbone. ${ }^{8 \mathrm{~b}}$

In this study we present the synthesis and characterization of new organonickel(II) species in which modified NCN ligands carry substituents on the aryl ring para to

(8) (a) van de Kuil, L. A.; Groot, P. M. F. C.; van Rijswijk, J.-P.; Grove, D. M.; Zwikker, J. W.; Jenneskens, L. W.; Drenth, W.; van Koten, G. Unpublished results. (b) van de Kuil, L. A.; Grove, D. M.; Vlietstra, E. J.; Vedral, S. A.; Zwikker, J. W.; Jenneskens, L. W.; Drenth W., van Koten, $\mathrm{G}$. Unpublished results.

(9) Inorganic Syntheses; Parshall, G. W., Ed.; Mcgraw-Hill: New York, 1974; Vol. XV, pp 5-9. the nickel-carbon bond and report interesting correlations between their spectroscopic and chemico-physical properties.

\section{Results}

Syntheses of Aryl Bromides. Several aryl bromides, $\mathrm{BrC}_{6} \mathrm{H}_{2}\left(\mathrm{CH}_{2} \mathrm{NMe}_{2}\right)_{2}-2,6-\mathrm{R}-4$ (1a-h), carrying various substituents on the aryl ring, para to the bromide, were synthesized. Compound la $(\mathrm{R}=\mathrm{H})$ was obtained via literature procedures, $4,10-12$ and this was the starting compound for the synthesis of aryl bromides $1 \mathbf{b}-\mathbf{f}$, as shown in Scheme 1. Compound $\mathbf{1 b}\left(\mathrm{R}=\mathrm{NO}_{2}\right)$ was prepared by nitration at the para position of $1 \mathrm{a}$ using $\mathrm{H}_{2} \mathrm{SO}_{4}$ and $\mathrm{HNO}_{3} .{ }^{15}$ Compound $1 \mathrm{c}\left(\mathrm{R}=\mathrm{NH}_{2}\right)$ was then obtained by reduction ${ }^{16}$ of nitro compound $1 \mathrm{~b}$ in the presence of hydrazine monohydrate in ethanol with $10 \% \mathrm{Pt} / \mathrm{C}$ or $5 \%$

(10) (a) Galli, C. J. Chem. Soc., Perkin Trans. 21981,$1459 ; 1982,1141$. (b) Vogel, A. Textbook of Practical Organic Chemistry, 4th ed.; Longman Inc.: New York, 1986; pp 687-703.

(11) (a) Vögtle, F. Chem, Ber, 1969, 102, 1784. (b) Offermann, W. Vögtle, F. Angew. Chem. 1980, 92, 471. (c) Horner, L.; Winkelmann, E. H. Angew. Chem. 1959, 71, 349 .

(12) Korn, N.; Huang, C. C.; Seevers, R. H.; Rothwell, C.; Counsell, R.

E. Int. J. Nucl. Med. Biol. 1979, 6, 153.

(13) Coucouvanis, D.; Lippard, S. J.; Zubieta, J. A. J. Am. Chem. Soc. $1970,92,3342$. 2855 . 
$\mathrm{Ru} / \mathrm{C}$ as catalyst. ${ }^{17}$ The aryl bromide $1 \mathrm{c}$ was then used for the syntheses of $1 d-f$. Compound $1 d(R=M e C(O) N-$ $(\mathrm{H}))$ was synthesized by reacting $1 \mathrm{c}$ with acetyl chloride in the presence of $\mathrm{Et}_{3} \mathrm{~N} .{ }^{18}$ Compound $1 \mathrm{e}(\mathrm{R}=\mathrm{Cl})$ was obtained by substituting the $\mathrm{NH}_{2}$ group of $1 \mathrm{c}$ with chloride in a classical Sandmeyer reaction. ${ }^{10}$ Compound if $(R=$ $\mathrm{PhCH}=\mathrm{N}$ ) was the result of a condensation reaction of 1c with benzaldehyde. ${ }^{19}$ The synthetic route to aryl bromide $1 \mathrm{~g}(\mathrm{R}=\mathrm{MeO})$ starts from 3,5-dimethylphenol, which was treated with $\mathrm{MeI}$ and $\mathrm{K}_{2} \mathrm{CO}_{3}$ in DMSO to afford the intermediate compound 3,5-dimethylanisole. ${ }^{20}$ Subsequent selective bromination of the arene ring with bromine in glacial acetic acid afforded 4-bromo-3,5dimethylanisole. ${ }^{20}$ Bromination of the methyl groups was then accomplished with $N$-bromosuccinimide (NBS) in $\mathrm{CCl}_{4 .}{ }^{11}$ Finally, the benzylic bromines were replaced by dimethylamino substituents using $\mathrm{HNMe}_{2}$ to afford the aryl bromide 1g. ${ }^{12}$ The synthesis of $1 \mathrm{~h}(\mathrm{R}=\mathrm{MeC}(\mathrm{O}))$ started with a Friedel-Crafts acylation of 2-bromo-m xylene. ${ }^{21}$ Although acylation may occur at either the meta or the para position with respect to the bromine substituent, acylation under thermodynamic control yields exclusively the desired 4-bromo-3,5-dimethylacetophenone. The penultimate step (the bromination with NBS) and the final step (the introduction of dimethylamino substituents) in the conversion of 2-bromo- $m$-xylene to $1 \mathrm{~h}$ were executed as those for $1 \mathrm{~g}$.

Synthesis of the Organonickel(II) Complexes 2ah. The syntheses of the organonickel(II) complexes $2 \mathbf{a}-\mathbf{h}$ (see Figure 1) is based on the route we described earlier, ${ }^{4}$ i.e. by an oxidative addition of the appropriate aryl bromide $(\mathbf{l a}-\mathbf{h})$ to $\mathrm{Ni}^{0}(\mathrm{COD})_{2}(\mathrm{COD}=$ cycloocta-1,5-diene). In all cases the procedure followed was the same and involved mixing of the starting compounds at $-78^{\circ} \mathrm{C}$ and then raising the temperature of the reaction mixture slowly to ambient; the onset of the reaction was indicated by a color change (from yellow to orange-brown) of the reaction mixture at higher temperatures. Interestingly, this conversion to the corresponding organonickel(II) complexes was strongly affected by the nature of the para substituent. For electron-withdrawing para substituents $\left(\mathrm{NO}_{2}, \mathrm{MeC}\right.$ $(\mathrm{O})$, and $\mathrm{Cl}$ ) the color change was observed at a distinctly lower temperature than that in the case of electrondonating para substituents $(\mathrm{MeC}(\mathrm{O}) \mathrm{N}(\mathrm{H}), \mathrm{MeO}$, and $\mathrm{NH}_{2}$ ); the onset temperature ranged from ca. $-40^{\circ} \mathrm{C}$ for $\mathrm{NO}_{2}$ to ca. $+20^{\circ} \mathrm{C}$ for $\mathrm{NH}_{2}$.

(15) (a) Hoggett, J. G.; Moodie, R. B.; Penton, J. R.; Schotfield, K. In Nitration and Aromatic Reactivity; Cambridge University Press: Cambridge, U.K., 1971; pp 125-129, 163-190. (b) Bennett, G. M.; Brand, J. C. D.; Williams, G. J. Chem. Soc. 1947, 474. (c) Bennett, G. M.; Brand, J. C. D. James, D. M.; Saunders, T. G.; Williams, G. J. Chem. Soc. 1946, 869. (d) Bayliss, N. S.: Watt, D. W. Aust. J. Chem. 1963, 16, 943. (e)

Vogel, A. Textbook of Practical Organic Chemistry, 4th ed.; Longman Inc.: New York, 1986; p 1108.

(16) When $\mathrm{Pd} / \mathrm{C}$ was used, dehalogenation of the arene ring was found: Mosby, W. L. J. Org. Chem. 1959, 24, 421.

(17) (a) Furst, A.; Berlo, R. C.; Hooton, S. Chem. Rev. 1965, 65, 51-68. (b) Kuhn, L. P. J. Am. Chem. Soc. 1951, 73, 1510. (c) Rottendorf, H. Sternhell, S. Aust. J. Chem. 1963, 16, 647. (d) Balcom, D.; Furst, A. J. Am. Chem. Soc. 1953, 75, 4334.

(18) Beckwith, A. L. J. In The Chemistry of Amides; Patai, S., Ed.; Interscience: London, 1970; pp 73-187.

(19) Dayagi, S.; Degani, Y. In The Chemistry of the Carbon-Nitrogen Double Bond; Patai, S., Ed.; Interscience: London; 1970, pp 61-149.

(20) (a) Fuson, R. C.; Corse, J.; Welldon, P. B. J. Am. Chem. Soc. 1941 63, 2645. (b) Lednicer, D.; Hauser, C. R. J. Chem. Soc. 1958, 23, 2008. (c) Honkanen, E. Acta Chem. Scand. 1959, 13, 1189. (d) Edwards, J. D. Cashaw, J. L. J. Am. Chem. Soc. 1956, 78, 3821.

(21) Sandler, S. R.; Karo, W. In Organic Functional Group Preparations, 2nd ed.; Academic Press: New York, 1983; Vol. I, pp 215-217 (Vol. 12 of Organic Chemistry, a series of monographs, Wasserman, $\mathrm{H}$. H., Ed.).
Table 1. Selected ${ }^{13} \mathrm{C}$ NMR Data* for Aryl Bromides 1a-h and for the Organonickel Complexes 2a-h with $\sigma_{p}$ Values for the Substituents R $(a-h)$

\begin{tabular}{|c|c|c|c|}
\hline \multirow[b]{2}{*}{$\begin{array}{c}\text { para substituent } \\
\text { (R) }\end{array}$} & \multirow[b]{2}{*}{$\sigma_{p}^{b}$} & \multicolumn{2}{|c|}{$\delta \mathrm{C}_{\mathrm{ipso}}$} \\
\hline & & aryl bromides ${ }^{c}$ & $\begin{array}{c}\text { organonickel(II) } \\
\text { complexes }^{d}\end{array}$ \\
\hline $\mathrm{NO}_{2}$ & 0.81 & 133.0 & $f$ \\
\hline $\mathrm{MeC}(\mathrm{O})$ & 0.47 & 132.4 & 162.3 \\
\hline $\mathrm{Cl}$ & 0.22 & 124.2 & 148.4 \\
\hline $\mathrm{H}$ & 0.00 & 127.0 & 150.4 \\
\hline $\mathrm{MeC}(\mathrm{O}) \mathrm{N}(\mathrm{H})$ & -0.09 & 120.5 & 144.3 \\
\hline $\mathrm{MeO}$ & -0.28 & 117.1 & 139.2 \\
\hline $\mathrm{NH}_{2}$ & -0.57 & 114.9 & 136. \\
\hline $\mathrm{PhCH}=\mathrm{N}$ & $e$ & 124.0 & 148.1 \\
\hline
\end{tabular}

${ }^{a} \delta$ in ppm relative to TMS; for the full ${ }^{13} \mathrm{C}$ and ${ }^{1} \mathrm{H}$ data see the Experimental Section. ${ }^{b}$ Values from ref $19 .{ }^{c}$ In $\mathrm{CDCl}_{3}{ }^{d}$ In $\mathrm{CD}_{3} \mathrm{OD}$. e Value not known. $f$ Complex $2 b$ could not be synthesized; see text.

It must be noted that the reaction of the $p$-nitroaryl bromide $1 \mathbf{b}$ with $\mathrm{Ni}(\mathrm{COD})_{2}$ did not lead to the desired organonickel(II) complex 2b. Although at $-40^{\circ} \mathrm{C}$ the reaction mixture did undergo a change from a yellow suspension to a orange-brown solution, $2 b$ could not be isolated; only starting material and an intractable black solid were recovered.

The organonickel(II) complexes $2 a$ and $\mathbf{2 c - h}$ are slightly air-sensitive, orange, crystalline solids which can be stored safely for several years under a nitrogen atmosphere. These organonickel(II) complexes dissolve readily in $\mathrm{CH}_{2} \mathrm{Cl}_{2}$, $\mathrm{MeOH}, \mathrm{CH}_{3} \mathrm{CN}$, and benzene. However, the stability of these complexes in solution depends strongly on the nature of the para substituent; complexes with electron-donating para substituents decompose more readily than the others. In air these nickel complexes react with compounds of the type $\mathrm{CXY}_{3}(\mathrm{X}=\mathrm{H}$ or halogen and $\mathrm{Y}=$ halogen) with an accompanying color change of their solutions from orange to green. This later color is indicative of the presence of organonickel(III) species that result from oxidation of the $\mathrm{Ni}(\mathrm{II})$ complexes. ${ }^{22}$

Characterization of the Aryl Bromides 1a-h and Organonickel(II) Complexes 2a and 2c-h. The aryl bromides were characterized by ${ }^{1} \mathrm{H}$ and ${ }^{13} \mathrm{C}$ NMR spectroscopy (see Experimental Section) and UV/vis spectroscopy. The organonickel(II) complexes, however, were subjected to a more detailed characterization, including elemental analysis and FAB mass spectrometry $(2 \mathbf{a}, \mathbf{c}, \mathbf{e , g}, \mathbf{h})$ (see Experimental Section), ${ }^{1} \mathrm{H}$ and ${ }^{13} \mathrm{C}$ NMR spectroscopy, UV/vis spectroscopy, and cyclic voltammetry.

${ }^{13}$ C NMR Spectroscopy. Since we were interested in the influence of the para substituent on the ${ }^{13} \mathrm{C}$ chemical shift of $\mathrm{C}_{\mathrm{ipso}}$ (i.e. $\delta\{\mathrm{CBr}\}$ and $\delta\{\mathrm{CNi}\}$ ), special attention was paid to the detection of these quaternary signals in the spectra of the aryl bromides 1 and the organonickel(II) complexes 2. These selected data are collected in Table 1. From these data we have identified a correlation between the Hammett $\sigma_{p}$ values of the para substituents (Exner's compilation ${ }^{23}$ ) and the chemical shift difference $(\Delta \delta\{\mathrm{CBr}\}$ and $\Delta \delta\{C \mathrm{Ni}\})$ between $\mathrm{C}_{\mathrm{ipso}}$ of the para-substituted compound 1 (or complex 2) and the parent species $1 \mathrm{a}$ (or 2a) which bears a para $\mathrm{H}$ substituent. Thus defined $\Delta \delta\{C \mathrm{Br}\}=\left(\delta\{C \mathrm{Br}\}_{1}-\delta\{C \mathrm{Br}\}_{1 \mathrm{a}}\right)$ and $\Delta \delta\{C \mathrm{Ni}\}=\left(\delta\{C \mathrm{Ni}\}_{2}-\right.$ $\delta\{C \mathrm{Ni}\}_{2 a}$ ). Plots of $\Delta \delta\{C \mathrm{Br}\}$ and $\Delta \delta\{C \mathrm{Ni}\}$ against $\sigma_{p}$ are shown in Figure 2, and they show linear relationships with

(22) Grove, D. M.; van Koten, G.; Zoet, R.; Murrall, N. W.; Welch, A. J. J. Am. Chem. Soc. 1983, 105, 1379.

(23) Exner, O. Correlation Analysis of Chemical Data; Plenum Press: New York, 1988. 

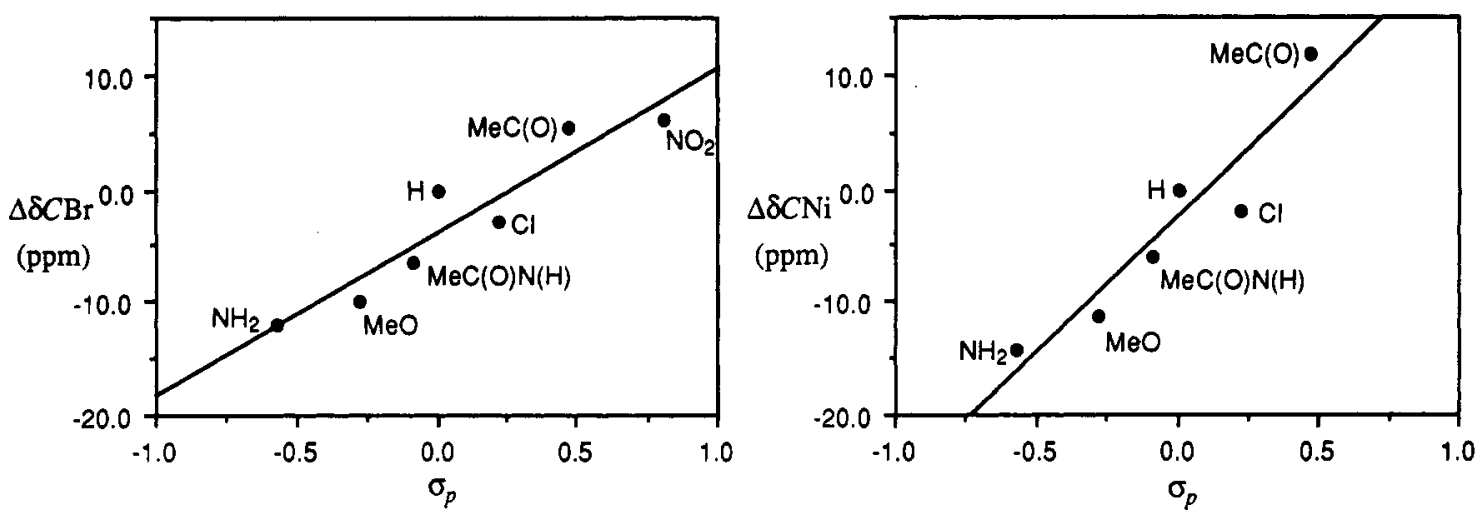

Figure 2. (a, left) Plot of $\triangle \delta\{\mathrm{Ar}\} C \mathrm{CBr}$ (see text) against $\sigma_{p}$ for the aryl bromides $\mathrm{BrC}_{6} \mathrm{H}_{2}\left(\mathrm{CH}_{2} \mathrm{NMe}_{2}\right)_{2}-2,6-\mathrm{R}-4(1 \mathrm{a}-\mathbf{h}), r=0.94$. (b, right) Plot of $\Delta \delta\{\mathrm{Ar}\} C \mathrm{CNi}$ (see text) against $\sigma_{p}$ for complexes $\left[\mathrm{NiI}^{\mathrm{II}}\left(\mathrm{C}_{6} \mathrm{H}_{2}\left(\mathrm{CH}_{2} \mathrm{NMe}_{2}\right)_{2}-2,6-\mathrm{R}-4\right\} \mathrm{Br}\right](2 \mathrm{a}-\mathbf{h}), r=0.94$.

Table 2. UV/Vis Data* for Compound 2a in Different Solvents

\begin{tabular}{llll}
\hline & & \multicolumn{1}{c}{$\lambda_{\max }(\epsilon)$} \\
\cline { 3 - 4 } solvent & $E_{\mathrm{T}^{b}}$ & MLCT band & \multicolumn{1}{c}{ aryl bands } \\
\hline $\mathrm{Et}_{2} \mathrm{O}$ & 34.6 & $462(356)$ & $309(4985), 257(20853), 218(7884)$ \\
$\mathrm{CH}_{2} \mathrm{Cl}_{2}$ & 41.1 & $459(360)$ & $308(4704), 253(16757), 228^{c}$ \\
$\mathrm{MeCN}^{4}$ & 46.0 & $414(385)$ & $291(10427), 237,{ }^{c} 216(37457)$ \\
$\mathrm{MeOH}$ & 55.5 & $432(318)$ & $293(3963), 237(10861), 212(10805)$ \\
$\mathrm{H}_{2} \mathrm{O}$ & 63.1 & $422(336)$ & $271(4799), 212(8340)$ \\
\multicolumn{1}{c}{${ }^{a} \lambda_{\max }$ in nm; $\epsilon$ in $\mathrm{L} \mathrm{mol}^{-1} \mathrm{~cm}^{-1}$ in parentheses. ${ }^{b} E_{\mathrm{T}}$ values taken from } \\
ref $20 .{ }^{c}$ Shoulder.
\end{tabular}

$r=0.94$ in both cases. As expected, electron-withdrawing substituents induce a downfield shift, while electrondonating substituents cause an upfield shift.

UV/Vis Measurements of Organonickel(II) Complexes $2 \mathrm{a}-\mathbf{h}$. The UV/vis spectrum of the parent compound $2 \mathrm{a}$ was measured in $\mathrm{CH}_{2} \mathrm{Cl}_{2}$ under argon. The weak absorption at $459 \mathrm{~nm}$ is assigned to the MLCT band (metalto-ligand charge transfer band), while absorptions in the region $220-310 \mathrm{~nm}$ can be ascribed to the aryl system of the organic ligand. The band positions of $2 a$ in the UV/ vis spectrum in $\mathrm{CH}_{2} \mathrm{Cl}_{2}$ have no significant temperature dependence in the range from -68 to $+21^{\circ} \mathrm{C}$, from which we conclude that the organonickel(II) complex has considerable rigidity that is probably resulting from the $\mathrm{N}, \mathrm{C}, \mathrm{N}^{\prime}$ terdentate bonding mode of the aryldiamine ligand to the metal. ${ }^{1}$

The effect of solvent polarity on the absorptions of $2 \mathrm{a}$ was also studied; see Table 2 . Using Reichardt's $E_{\mathrm{T}}$ values $^{24}$ for the polarity scale we find a substantial hypsochromic shift of the MLCT band with increasing polarity. With data in acetonitrile excluded (the only solvent with significant coordination properties) a correlation between the polarity of the solvent and the position of the MLCT band is observed $(r=0.99)$. Absorption bands originating from the aryl ligand also undergo hypsochromic shifts upon increasing solvent polarity.

Further UV/vis measurements were carried out on aryl bromides 1 and nickel complexes 2 in $\mathrm{CH}_{2} \mathrm{Cl}_{2}$ as a solvent in order to establish the influence of a para substituent, and these data are collected in Table 3. These data show that the absorption bands in the spectra of the substituted aryl bromides (1c,e,g,h) and their organonickel(II) complexes $(\mathbf{2 c}, \mathbf{e}, \mathbf{g}, \mathbf{h})$ show a bathochromic shift with respect to corresponding bands in the spectrum of the parent compounds $1 \mathbf{a}$ and $\mathbf{2 a}$, respectively. However, the position

(24) (a) Reichardt, C.; Harbusch-Görnert, E. Liebigs, Ann. Chem. 1980, 721. (b) Reichardt, C. Solvents and Solvent Effects in Organic Chemistry; VCH Verlagsgesellschaft mbH: Weinheim, 1988; pp 285-338. of the MLCT band present for the organonickel complexes is unaffected by para substitution, with the exception of the $\mathrm{MeC}(\mathrm{O})$ substituent which shows a small hypsochromic shift.

Redox Behavior of Organonickel(II) Complexes 2a, $2 c, 2 e, 2 g$, and $2 h$. Organonickel complexes of the type $\left.\left[\mathrm{Ni}{ } \mathrm{CC}_{6} \mathrm{H}_{3}\left(\mathrm{CH}_{2} \mathrm{NMe}_{2}\right)_{2}-2,6\right\} \mathrm{X}\right]$ can easily be oxidized either chemically by electrophilic reagents such as $\mathrm{Cu}^{\mathrm{II}} \mathrm{X}_{2}(\mathrm{X}=$ $\mathrm{Br}, \mathrm{Cl}$ ) and $\mathrm{I}_{2}$ or electrochemically to afford unique, fivecoordinate, $\mathrm{d}^{7}$ arylnickel(III) species, $\left[\mathrm{Ni}^{\mathrm{III}}\left\{\mathrm{C}_{6} \mathrm{H}_{3}\left(\mathrm{CH}_{2}\right.\right.\right.$ $\left.\left.\left.\mathrm{NMe}_{2}\right)_{2}-2,6\right\} \mathrm{X}_{2}\right](\mathrm{X}=\mathrm{Br}, \mathrm{Cl}, \mathrm{I}){ }^{22}$ The electrochemical oxidation of the nickel complex $2 \mathbf{a}$ has been studied by cyclic voltammetry, ${ }^{4 a}$ and the redox potential of the nickel center in organic solvents was found to be sensitive to the anion $\mathrm{X}$ present. For this reason the redox behavior of the para-substituted arylnickel complexes $2 c, 2 e, 2 g$, and $2 \mathrm{~h}$ in acetone and $\mathrm{CH}_{2} \mathrm{Cl}_{2}$ was also studied by cyclic voltammetry. All complexes $2 \mathrm{c}, 2 \mathrm{e}, 2 \mathrm{~g}$, and $2 \mathrm{~h}$ produce under the correct conditions (vide infra) cyclic voltammograms that correspond to the $\mathrm{Ni}{ }^{\mathrm{II}} / \mathrm{Ni}^{\mathrm{III}}$ redox couple with identical $i_{\mathrm{p}} / C$ values; i.e. as for $2 \mathrm{a}$ a one-electron transfer is established. It must be noted that due to the very different structures of the $\mathrm{Ni}$ (II) and $\mathrm{Ni}$ (III) complexes the anodic and cathodic waves in the cyclic voltammogram represent two distinct charge transfer processes $^{4 \mathrm{a}}$ (eqs 2 and 3 ) and that, consequently, there is

$$
\begin{gathered}
\mathrm{Br}^{-}+\left[\mathrm{Ni}^{\mathrm{II}}(p-\mathrm{R}-\mathrm{NCN}) \mathrm{Br}\right] \frac{-\mathrm{e}^{-}}{\frac{\left[\mathrm{Ni}^{\mathrm{III}}(p-\mathrm{R}-\mathrm{NCN}) \mathrm{Br}_{2}\right]}{\text { acetone or } \mathrm{CH}_{2} \mathrm{Cl}_{2}}} \\
{\left[\mathrm{Ni}^{\mathrm{III}}(p-\mathrm{R}-\mathrm{NCN}) \mathrm{Br}_{2}\right] \frac{+\mathrm{e}^{-}}{\text {acetone or } \mathrm{CH}_{2} \mathrm{Cl}_{2}}} \\
p-\mathrm{R}-\mathrm{NCN}=\left[\mathrm{C}_{6} \mathrm{H}_{2}\left(\mathrm{CH}_{2} \mathrm{NMe}_{2}\right)_{2}-2,6-\mathrm{R}-4\right]^{-}
\end{gathered}
$$

no formal electrochemical relationship between these two reactions. Furthermore, the appropriate anion should be present in solution during the oxidation process (see eq 2 ). In all these measurements, therefore, $\mathrm{Bu} \mathrm{NBr}_{4}$ was used as the supporting electrolyte in order to keep the anion (i.e. $\mathrm{Br}^{-}$) constant. Under these correct conditions the peak potentials for the oxidation $\left(E_{\mathrm{p}, \mathrm{a}}\right)$ and reduction $\left(E_{\mathrm{p}, \mathrm{c}}\right)$ were measured and the values are collected in Table 4. These data show that the para substituent significantly affects the redox behavior of these organonickel(II) complexes. There is a good correlation of the $E_{\mathrm{p}, \mathrm{a}}$ values 
Table 3. UV/Vis Data for Aryl Bromides 1a, 1c, 1e, $1 \mathrm{~g}$, and $1 \mathrm{~h}$ and Organonickel Complexes $2 \mathrm{a}, 2 \mathrm{c}, 2 \mathrm{e}, 2 \mathrm{~g}$, and $2 \mathrm{~h}$ in $\mathrm{CH}_{2} \mathrm{Cl}_{2}$

\begin{tabular}{|c|c|c|c|}
\hline \multirow{2}{*}{$\begin{array}{l}\text { substituent } \\
\text { (R) }\end{array}$} & \multirow[b]{2}{*}{$\sigma_{\mathrm{p}}^{b}$} & \multicolumn{2}{|c|}{$\lambda_{\max }(\epsilon)$} \\
\hline & & $\mathrm{BrC}_{6} \mathrm{H}_{2}\left(\mathrm{CH}_{2} \mathrm{NMe}_{2}\right)_{2}-2,6-\mathrm{R}-4$ & {$\left[\mathrm{Ni}\left\{\mathrm{C}_{6} \mathrm{H}_{2}\left(\mathrm{CH}_{2} \mathrm{NMe}_{2}\right)_{2}-2,6-\mathrm{R}-4\right\} \mathrm{Br}\right]$} \\
\hline $\begin{array}{l}\mathrm{MeC}(0) \\
\mathrm{Cl} \\
\mathrm{H} \\
\mathrm{MeO} \\
\mathrm{NH}_{2}\end{array}$ & $\begin{array}{l}0.47 \\
0.22 \\
0.00 \\
-0.28 \\
-0.57\end{array}$ & $\begin{array}{l}296, c^{c} 285(16125), 229^{c} \\
274, c 231(10690) \\
260, c 229(5960) \\
285(1902), 231(11042) \\
299(2317), 244(12123), 228^{c}\end{array}$ & $\begin{array}{l}452(554), 361(12415), 266(26844), 22^{c} \\
461(412), 312(6503), 255(24497), 228^{c} \\
459(360), 308(4704), 253(16757), 228^{c} \\
461(352), 328, c 293(7203), 253(24991), 229^{c} \\
461(518), 335, c 298(9688), 256(24176), 228^{c}\end{array}$ \\
\hline
\end{tabular}

${ }^{a} \lambda_{\max }$ in $\mathrm{nm} ; \epsilon$ in $\mathrm{L} \mathrm{mol}^{-1} \mathrm{~cm}^{-1}$. ${ }^{b} \sigma_{p}$ values from ref $19 .{ }^{c}$ Shoulder.

Table 4. Electrochemical Data for the Organonickel Complexes $\left[\mathrm{Ni}\left\{\mathrm{C}_{6} \mathrm{H}_{2}\left(\mathrm{CH}_{2} \mathrm{NMe}_{2}\right)_{2}-2,6-\mathrm{R}-4\right\} \mathrm{Br}\right]$ in $\mathrm{CH}_{2} \mathrm{Cl}_{2}{ }^{2}$

\begin{tabular}{lccc}
\hline & \multicolumn{3}{c}{ potentials $^{b}$} \\
\cline { 2 - 4 } compd (R) & $E_{\mathrm{p}, \mathrm{a}} / \mathrm{V}$ & $E_{\mathrm{p}, \mathrm{c}} / \mathrm{V}$ & $\Delta E_{\mathrm{p}} / \mathrm{mV}$ \\
\hline $2 \mathrm{~h}(\mathrm{MeC}(\mathrm{O}))$ & 0.616 & 0.476 & 140 \\
$2 \mathrm{e}(\mathrm{Cl})$ & 0.600 & 0.474 & 126 \\
$\mathbf{2 a}(\mathrm{H})$ & 0.574 & 0.394 & 180 \\
$2 \mathrm{~g}(\mathrm{MeO})$ & 0.550 & 0.388 & 162 \\
$2 \mathrm{c}\left(\mathrm{NH}_{2}\right)$ & 0.487 & 0.358 & 128
\end{tabular}

${ }^{a}$ Potentials referred to an $\mathrm{Ag} / \mathrm{AgI}\left(0.4 \mathrm{M} \mathrm{Bu}_{4} \mathrm{NClO}_{4}\right.$ and $0.05 \mathrm{M}$ $\mathrm{Bu}_{4} \mathrm{NI}$ ) electrode at a scan rate of $100 \mathrm{mV} \mathrm{s}$ s. $^{-1}$ and with $\mathrm{Bu} 4 \mathrm{NBr}$ as supporting electrolyte; $E_{1 / 2}$ for $\mathrm{Fc}^{+} / \mathrm{Fc}=+0.87 \mathrm{~V} .{ }^{b} E_{\mathrm{p}, \mathrm{a}}$ and $E_{\mathrm{p}, \mathrm{c}}$ are the peak potentials of the oxidation and reduction waves, respectively.

versus $\sigma_{p}$ values $(r=0.97)$, as shown in Figure 3 , with lower $E_{\mathrm{p}, \mathrm{a}}$ values corresponding to substituents with better electron-donating properties.

\section{Discussion}

Formation of the Organonickel(II) Complexes 2ah. The para substituents of the aryl bromides $1 \mathbf{a}-\mathbf{h}$ have a substantial effect on their oxidative addition to $\mathrm{Ni}^{0}$. $(\mathrm{COD})_{2}$; aryl bromides with electron-withdrawing substituents are more reactive than those with electrondonating substituents. We believe that this reaction involves an electron transfer mechanism like that originally proposed by us for the reaction of $\mathrm{BrC}_{6} \mathrm{H}_{3}\left(\mathrm{CH}_{2} \mathrm{NMe}_{2}\right)_{2-}$ 2,6 (1a) with $\mathrm{Ni}^{0}(\mathrm{COD})_{2}$ and for which the following pathway dominates: $1,5 \mathrm{a}$

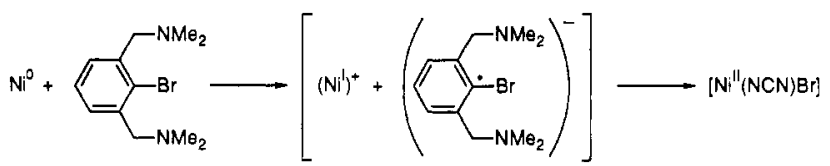

$\mathrm{NCN}=\left[\mathrm{C}_{6} \mathrm{H}_{3}\left(\mathrm{CH}_{2} \mathrm{NMe}_{2}\right)_{2}-2,6\right]$

Kochi et al. have studied the reaction of $\mathrm{Ni}(0)$ complexes with aromatic halides, and they proposed that electron transfer from $\mathrm{Ni}(0)$ to the electron-deficient aryl halide is the rate determining step. ${ }^{25}$ The essential intermediate is the formation of $\left[\mathrm{Ni}^{\mathrm{I}} \mathrm{L}_{3} \mathrm{ArX} \cdot-\right]\left(\mathrm{L}=\mathrm{PR}_{3}\right)$. Interestingly, the mechanistic proposal by Kochi also invokes the intermediacy of $d^{7} \mathrm{Ni}$ (III) species which, however, could not be substantiated by either isolation or spectroscopic measurements. In contrast, we could isolate significant amounts of a d ${ }^{7}$ arylnickel(III) compound [ $\mathrm{Ni}_{3} \mathrm{C}_{6} \mathrm{H}_{3}\left(\mathrm{CH}_{2^{-}}\right.$ $\left.\left.\mathrm{NMe}_{2}\right)_{2}-2,6\right\} \mathrm{Br}_{2}$ ] during the preparation of $2 \mathrm{a}^{4 \mathrm{a}}$ During the syntheses of the organonickel(II) complexes $2 \mathbf{c}-\mathbf{h}$ small amounts of poorly soluble $\left[\mathrm{Ni}^{\mathrm{III}}\left\{\mathrm{C}_{6} \mathrm{H}_{2}\left(\mathrm{CH}_{2} \mathrm{NMe}_{2}\right)_{2}-2,6-\mathrm{R}-\right.\right.$ $4\} \mathrm{X}_{2}$ ] are also formed, especially in the case of the nickel complexes with electron-donating substituents. Our ear-

(25) (a) Kochi J. K Organometallic Mechanisms and Catalysis Academic Press: New York, 1978. (b) Tsou, T. T.; Kochi, J. K. J. Am Chem. Soc. 1979, 6319. (c) Tsou, T. T.; Kochi, J. K. J. Am. Chem. Soc. 1979,7547 .

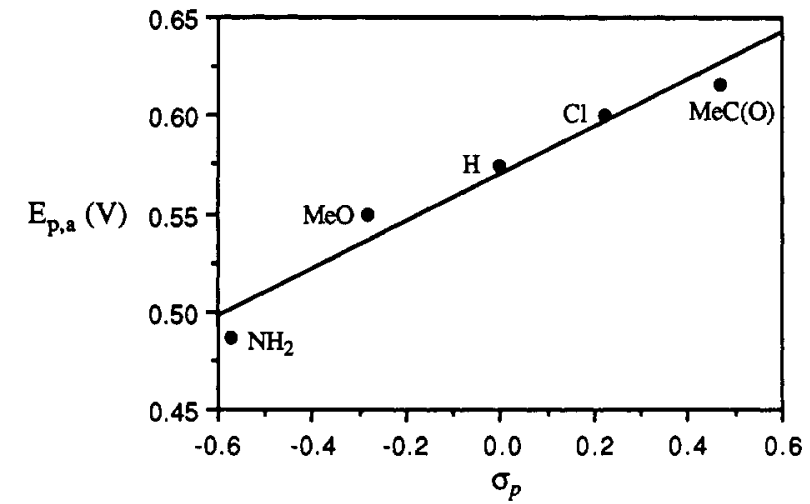

Figure 3. Correlation between $\sigma_{p}$ of the para substituent of the $\left[\mathrm{C}_{6} \mathrm{H}_{2}\left(\mathrm{CH}_{2} \mathrm{NMe}_{2}\right)_{2}-2,6-\mathrm{R}-4\right]^{-}$ligand and the oxidation potentials $\left(E_{\mathrm{p}, \mathrm{a}}\right)$ of organonickel(II) complexes $2 \mathrm{a}, 2 \mathrm{c}, 2 \mathrm{e}, 2 \mathrm{~g}$, and $\mathbf{2 h}$.

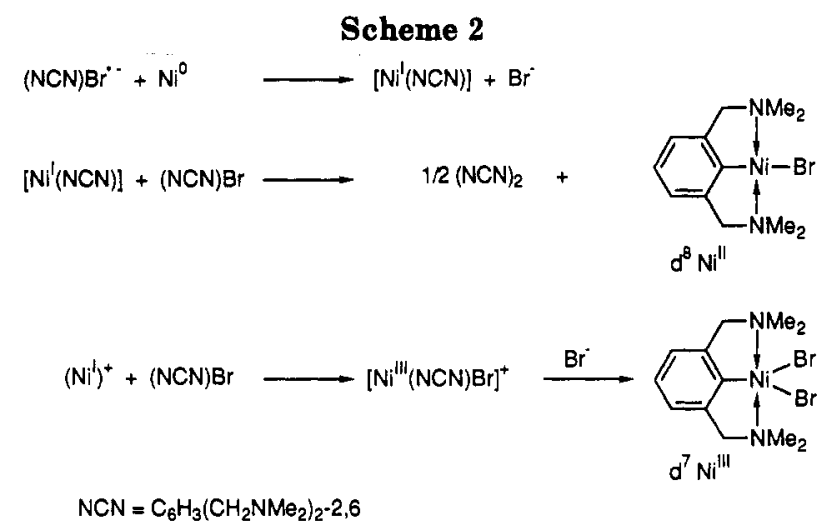

lier and present findings regarding the formation of these $\mathrm{Ni}$ (III) complexes support the postulate that $\mathrm{Ni}$ (III) intermediates play an important role in the aryl coupling reactions of aryl halides (ArX) with arylnickel(II) halide complexes, ${ }^{25 \mathrm{c}}$ with the side reactions in Scheme 2 being relevant. ${ }^{4}$

Experiments by Cassar et al. have shown that metaand para-substituted aryl halides, especially those with electron-withdrawing substituents, have a pronounced effect on the rate at which the initial intermediate $\left[\mathrm{Ni}^{I} \mathrm{~L}_{3} \mathrm{ArX}{ }^{-}\right]$is formed in the reaction of $\mathrm{ArX}$ with $\left[\mathrm{Ni}^{0} \mathrm{~L}_{4}\right]$ $\left(\mathrm{L}=\mathrm{PR}_{3}\right){ }^{26}$ With increasing electron affinity of the aryl system, by introduction of electron-withdrawing para substituents, the electron transfer from the $\mathrm{Ni}(0)$ donor to the aryl halide is facilitated.

From our cyclovoltammetry results we know that the electronic properties of the $\mathrm{Ni}$ (II) complexes $2 \mathbf{a}-\mathbf{h}$ are influenced by the para substituent. In particular when the $\mathrm{Ni} i^{I} / \mathrm{Ni}^{\mathrm{II}}$ oxidation potential $E_{\text {or }}$ is lowered by electrondonating para substituents, one expects that electron transfer from the $\mathrm{Ni}$ (II) complex to ArX can occur more

(26) Foà, M.; Cassar, L. J. Chem. Soc., Dalton Trans. 1975, 2572.

(27) Berman, R. S.; Kochi, J. K. Inorg. Chem. 1980, 19, 248. 
readily and that formation of $\mathrm{Ni}(\mathrm{III})$ species should be easier. Due to the special coordinating properties of the di-ortho-amino-substituted aryl ligand $\left[\mathrm{C}_{6} \mathrm{H}_{2}\left(\mathrm{CH}_{2} \mathrm{NMe}_{2}\right)_{2}\right.$ 2,6-R-4]- we can anticipate stabilization of such Ni(III) species. The comparatively low yields of the Ni(II) complexes with electron-donating para substituents $\mathrm{MeO}$ and $\mathrm{NH}_{2}$ (see Experimental Section) appear to reflect this behavior, i.e. the more ready formation of $\mathrm{Ni}$ (III) byproducts.

In our hands oxidative addition of aryl bromide $1 \mathbf{b}$ (with a para nitro group) to $\mathrm{Ni}(\mathrm{COD})_{2}$ does not afford $\mathbf{2 b}$, and this result indicates the dominance of other competitive reactions. The most likely possibility is reaction of the nitro functionality with the zerovalent nickel center whereby oxygen transfer from the nitro group to a suitable substrate is the final result. ${ }^{28}$

Electrochemical Measurements. The effect of para substitution of the organic ligand on the redox properties of the organonickel(II) complexes $2 \mathrm{a}, 2 \mathrm{c}, 2 \mathrm{e}, 2 \mathrm{~g}$, and $2 \mathrm{~h}$ was quantified by electrochemical measurements; the oxidation potential is found to be sensitive to such substitution. The oxidation potentials $\left(E_{\mathrm{p}, \mathrm{a}}\right)$ for the organonickel complexes $2 \mathbf{a}, 2 \mathbf{c}, 2 \mathrm{e}, 2 \mathrm{~g}$, and $2 \mathbf{h}$ in $\mathrm{CH}_{2} \mathrm{Cl}_{2}$ vary from $0.49 \mathrm{~V}$ for $\mathrm{NH}_{2}$, the strongest electron-donating substituent, to $0.62 \mathrm{~V}$ for $\mathrm{MeC}(0)$, the most electronwithdrawing substituent. Thus variation in the para substituent is an effective way of tuning the electronic properties of the metal center. Our earlier studies of the redox behavior of the nickel(II) complexes, $\left[\mathrm{Ni}\left\{\mathrm{C}_{6} \mathrm{H}_{3}\left(\mathrm{CH}_{2}\right.\right.\right.$ $\left.\left.\left.\mathrm{NMe}_{2}\right)_{2}-2,6\right\} \mathrm{X}\right]$ and the corresponding, independently prepared nickel(III) species, $\left[\mathrm{Ni}\left\{\mathrm{C}_{6} \mathrm{H}_{3}\left(\mathrm{CH}_{2} \mathrm{NMe}_{2}\right)_{2}-2,6\right\}\right.$ $\left.\mathrm{X}_{2}\right]\left(\mathrm{X}=\mathrm{Cl}, \mathrm{Br}\right.$ and $\left.\mathrm{NO}_{3}\right)$ showed that the $\mathrm{Ni}(\mathrm{II}) / \mathrm{Ni}(\mathrm{III})$ couple had a low redox potential that could be varied by the anion. ${ }^{4 a}$ The combination of anion and para substituent variation that is now available is a powerful tool for controlling the reactivity of these catalytically active complexes. $^{8}$

UV/Vis Spectroctroscopy. The MLCT absorption band of 2a undergoes a hypsochromic (blue) shift in more polar solvent media; i.e. it exhibits negative solvatochromism. This type of behavior, which is probably charge transfer in character, is in line with literature data for MLCT bands and can be interpreted in terms of a reduced excited state electric dipole. This can be rationalized by invoking a ground state that possesses considerable polar character which is reduced upon excitation. ${ }^{28} \mathrm{~A}$ polar medium can be considered to stabilize the ground state to a greater extent than the excited state, and consequently, the energy gap for the $S_{0} \rightarrow S_{1}$ transition will increase and a hypsochromic shift will result.

The UV/vis data show that introduction of a substituent at the para position of aryl bromides 1 and organonickel(II) complexes 2 produces a bathochromic shift with respect to $1 \mathbf{a}$ and $2 a(R=H)$, respectively, as references. The monosubstitution of benzene shows a similar effect, ${ }^{29}$ and this is caused by the change in relative energies of the molecular orbitals of the molecule (i.e. the energy of the LUMO does not change, while the energy of the HOMO is raised) so that the gap between these two molecular

(28) (a) Kaim, W.; Kohlmann, S.; Ernst, S.; Olbrich-Deussner, B.; Bessenbacher, C.; Schulz, A. J. Organomet. Chem. 1987, 321, 215. (b) Manuta, D. M.; Lees, A. J. Inorg. Chem. 1986, 25, 3212. orbitals will be less. This lowering in transition energy will correspond to a longer wavelength. Substituents on benzene all cause a bathochromic shift regardless of their electronic character.

${ }^{13} \mathrm{C}$ NMR Spectroscopy. The use of ${ }^{13} \mathrm{C}$ NMR data to investigate the effect of substitution on the electronic properties of aromatic systems is a powerful tool..$^{30}$ To a first approximation, the ${ }^{13} \mathrm{C}$ chemical shifts of carbon atoms in a cyclic $\pi$-system are a measure of the $\pi$-electron density of these individual ring carbon atoms. The $\pi$-electron density depends on several factors such as inductive and resonance effects and magnetic anisotropy contributions. Several relationships between the chemical shift and quantities that measure the distribution of electron density in the benzene ring have been used. In particular, a good linear relation is observed for the ${ }^{13} \mathrm{C}$ chemical shift of a carbon atom para-positioned to a substituent and the Hammett substituent constant $\sigma$. The major contribution to the chemical shift of this carbon atom can be attributed to resonance interactions of the substituent with the aryl ring. ${ }^{30}$ In our system this para-positioned carbon atom in the aryl bromides 1 and the organonickel(II) complexes 2 is the $\mathrm{C}_{\text {ipso }}$ atom attached to $\mathrm{Br}$ or $\mathrm{Ni}$, respectively.

For the series $1 \mathrm{a}-\mathrm{h}$ and $2 \mathrm{a}$ and $\mathbf{2 c - h}$ we find a good linear relation between the Hammett constant $\sigma_{p}$ and $\delta$ $\{\mathrm{Ar}\} \mathrm{CBr}$ and $\delta\{\mathrm{Ar}\} \mathrm{CNi}$ (Figure 2). An even better correlation is found with use of Taft's resonance parameters $\sigma^{0} \mathrm{R}$ and "corrected" para carbon shifts, which are defined as $\delta \mathrm{C}_{p}-\delta \mathrm{C}_{m}$; i.e. in the present system it is defined as $\delta \mathrm{C}_{\mathrm{ipso}}-\delta \mathrm{C}_{\text {ortho }}$. It was stated that in this way factors other than resonance contributions would be eliminated, ${ }^{31}$ and the corrected value would then be a measure of the local $\pi$-electron density due solely to resonance interaction of the substituent with the ring. For the compounds of series 1 and 2 a plot of $\delta \mathrm{C}_{\text {ipso }}-\delta \mathrm{C}_{\text {ortho }}$ versus $\sigma_{\mathrm{R}}{ }_{\mathrm{R}}$ is depicted in Figure 4. The correlation coefficients now increase to $r$ $=0.99$ for the aryl bromides and $r=0.98$ for the organonickel complexes. Although this type of correlation was initially developed for monosubstituted benzenes, ${ }^{30,32}$ it can also be applied to multisubstituted aromatic ring systems, provided that it is a series of compounds in which only one substituent is varied while others remain fixed.

This study shows that the electron density on the $\{\mathrm{Ar}\}$ $\mathrm{CNi}$ carbon atoms is markedly affected by para substituents on the aryl ring. Electron-donating substituents cause an upfield shift, indicating a shielding of the ipsocarbon atom and hence a higher electron density at this donor atom. Consequently, we anticipate that the electron density on the neighboring nickel atom will also be affected; i.e. it will be higher with electron-donating para substituents. In its turn, the higher the electron density on the nickel atom the lower will be the oxidation potential of the organonickel(II) complex. Since the ease with which these complexes can be oxidized is a major factor in their

(29) (a) Doub, L.; Vandenbelt, J. M. J. Am. Chem. Soc. 1947, 69, 2714. (b) Jaffee, H. H.; Orchin, M. In Theory and Applications of Ultraviolet Spectroscopy; John Wiley \& Sons, Inc.: New York, 1964; pp 242-287. (c) Duben, A. L. J. Chem. Educ. 1985, 62, 373.

(30) (a) Speisecke, H.; Schneider, W. G. J. Phys. Chem. 1961, 35, 731 (b) Hinton, J. F.; Layton, B. Org. Magn. Reson. 1972, 4, 353. (c) Nelson, G. L.; Williams, E. A. Prog. Phys. Org. Chem. 1976, 12, 229. (d) Ewing, D. F. In Correlation Analysis in Chemistry: Recent Advances; Chapman, N. B., Shorter, J., Eds.; Plenum Press: New York, 1978; p 357. (e) Kalinowski, H. O.; Berger, S.; Braun, S. Carbon-13 NMR Spectroscopy: John Wiley \& Sons Ltd.; New York, 1988; pp 104-113 and 311-340.

(31) Maciel, G. E.; Natterstad, J. J. J. Chem. Phys. 1965, 42, 2427.

(32) (a) Bromilow, J.; Brownlee, R. T. C.; Lopez, V. O.; Taft, R. W. J. Org. Chem. 1979, 44, 4766. (b) Bromilow, J.; Brownlee, R. T. C.; Craik, D. J.; Sadek, M.; Taft, R. W. J. Org. Chem. 1980, 45, 2429. 

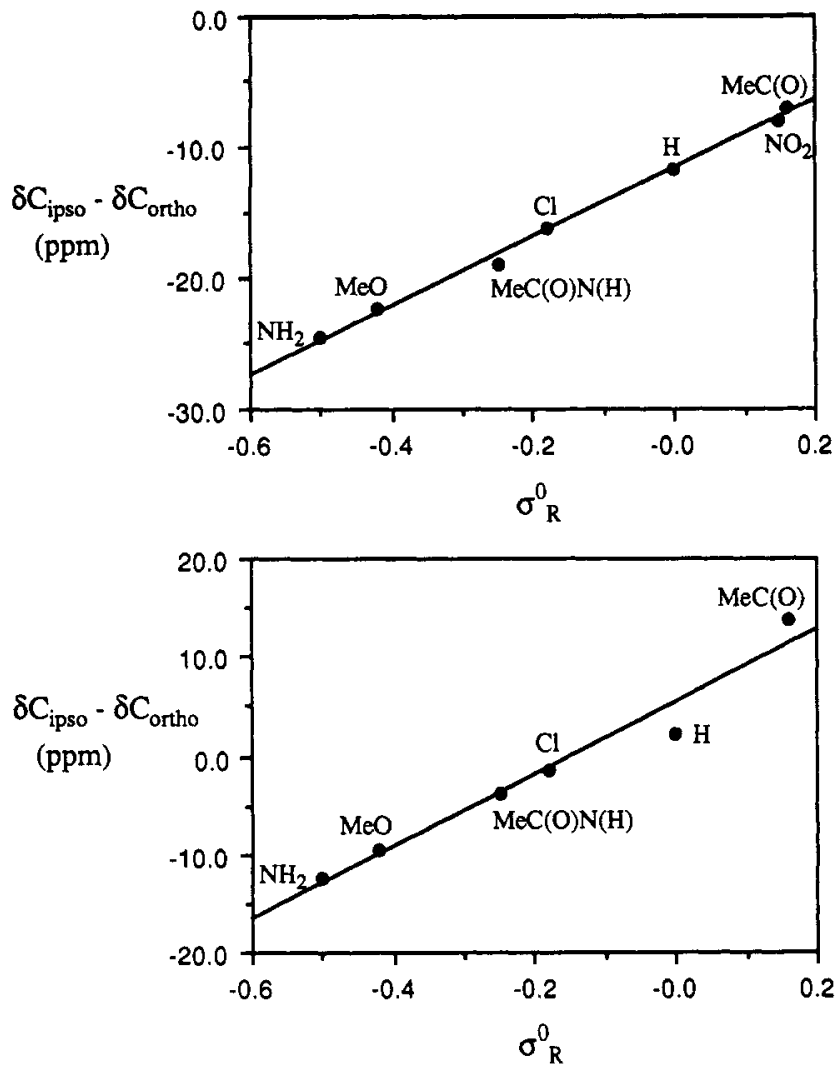

Figure 4. Plots of the "corrected" para carbon chemical shift versus $\sigma^{0}$ : (upper graph) aryl bromides $1 \mathbf{a}-\mathbf{h}(r=0.99$ ); (lower graph) organonickel(II) complexes $2 \mathrm{a}-\mathrm{h}(r=0.98)$. The $\sigma^{0} \mathrm{R}$ values are from ref 25 and, for $\mathrm{MeC}(\mathrm{O}) \mathrm{N}(\mathrm{H})$ and $\mathrm{MeC}(\mathrm{O})$, from ref 19 .

catalytic activity, ${ }^{6}$ substitution on the aryl ring will directly affect their catalytic behavior. This behavior is the subject of a forthcoming paper. ${ }^{8 \mathrm{a}}$

\section{Conclusions}

Our experimental data show that the para substituent in the ligands $\left[\mathrm{C}_{6} \mathrm{H}_{2}\left(\mathrm{CH}_{2} \mathrm{NMe}_{2}\right)_{2}-2,6-\mathrm{R}-4\right]^{-}$has a pronounced effect on the electronic properties of the corresponding nickel(II) complexes. This approach for modifying the properties of the metal center has great potential for tuning the reactivity of these nickel(II) complexes. ${ }^{33}$ Our first results show that the catalytic activity of these organonickel(II) complexes in the Kharasch addition reaction of polyhalogenated alkanes to alkenes (see eq 1) is indeed affected by para substitution: the better the electron-donating properties of the substituent the higher the reactivity of the nickel complexes. ${ }^{8}$ An important feature of this type of ligand modification is the fact that the catalytic matrix - the metal coordination sphereremains stereochemically identical and is only subject to electronic influence through the $\mathrm{C}_{\mathrm{ipso}}-\mathrm{Ni}$ bond.

\section{Experimental Section}

General Considerations. All reactions affording the aryl bromides (1a-h) and their corresponding organonickel(II) complexes $(2 a-h)$ were carried out under a dry nitrogen atmosphere using Schlenk techniques. Unless otherwise stated solvents were freshly distilled and dried before use. All reagents are commercially available and have been used without further purifi-

(33) Jacobsen, E. N.; Zhang, W.; Güler, M. L. J. Am. Chem. Soc. 1991, 113,6703 . cation except for $\mathrm{Ni}(\mathrm{COD})_{2}(\mathrm{COD}=$ cycloocta-1,5-diene $)$ which was prepared according to a literature procedure. ${ }^{1}{ }^{1} \mathrm{H}$ NMR and ${ }^{13} \mathrm{C}$ NMR spectra were recorded on a Bruker $\mathrm{AC} 300$ spectrometer operating at 300 and $75.47 \mathrm{MHz}$, respectively. The NMR spectra were recorded in $\mathrm{CDCl}_{3}, \mathrm{CD}_{2} \mathrm{Cl}_{2}$, and $\mathrm{CD}_{3} \mathrm{OD}$. Abbreviations used are as follows: s, singlet, d, doublet, t, triplet, q, quartet, $\mathrm{m}$, multiplet, br, broad. UV/vis spectra were measured on a Varian Cary 1. FAB mass spectra were obtained using a VG ZAB 2F instrument. Elemental analyses were carried out by Mikroanalytisches Laboratorium Dornis and Kolbe, Mülheim a. d. Ruhr, Germany, and by the Institute for Applied Chemistry, TNO, Zeist, The Netherlands.

Synthesis. 2-Bromo-1,3-dimethylbenzene (2-Bromo-mxylene). This compound was synthesized according to a literature procedure..$^{10}$ 2,6-Dimethylaniline $(500 \mathrm{~g}, 4.1 \mathrm{~mol})$ was dissolved in $48 \%$ hydrobromic acid $(2.2 \mathrm{~L})$ and the solution was cooled to $0^{\circ} \mathrm{C}$. To this mechanically stirred solution was added in small portions, sodium nitrite $(320 \mathrm{~g}, 4.6 \mathrm{~mol})$, while the temperature of the reaction mixture was maintained below 10 ${ }^{\circ} \mathrm{C}$. During the reaction gas evolution was observed. The reaction mixture was stirred for $16 \mathrm{~h}$, while the temperature was slowly raised to room temperature. When gas evolution had stopped, the crude product was isolated by steam distillation. The first orange fraction was collected separately and discarded. To each liter of the yellow distillate was added $10 \mathrm{~g}$ of sodium hydroxide. Subsequently, the organic layer was separated and washed with $6 \mathrm{M} \mathrm{HCl}, 4 \mathrm{M} \mathrm{NaOH}(6 \times)$, and $\mathrm{H}_{2} \mathrm{O}$. After drying over $\mathrm{MgSO}_{4}$, the organic product was distilled under reduced pressure $\left(43^{\circ} \mathrm{C}\right.$ at $1.0 \mathrm{mmHg}$ ). A colorless oil was obtained, $412 \mathrm{~g}$ ( $53.9 \%$ yield). ${ }^{1} \mathrm{H}$ NMR $\left(\mathrm{CDCl}_{3}\right): \delta 2.43\left(\mathrm{~s}, 6 \mathrm{H}, \mathrm{CH}_{3}\right), 7.07$ (s, $\left.3 \mathrm{H}, \mathrm{ArH}\right)$.

2-Bromo-1,3-bis(bromomethyl)benzene. This compound was synthesized according to a modified literature procedure. ${ }^{11}$ To a stirred solution of 2,6-dimethylbromobenzene $(100 \mathrm{~g}, 0.54$ $\mathrm{mol})$ in $\mathrm{CCl}_{4}(600 \mathrm{~mL})$ were added 2 equiv of $N$-bromosuccinimide (NBS) $(192.5 \mathrm{~g}, 1.08 \mathrm{~mol})$ and a catalytic amount of $2,2^{\prime}$-azobis(2-methylpropionitrile) (AIBN). The reaction mixture was brought to reflux and kept there until all the NBS had reacted away and a white succinimide layer floated on the $\mathrm{CCl}_{4}$ solution. The reaction mixture was then cooled to room temperature and filtered over a G4 glass frit. The filtrate was collected and concentrated by rotary evaporation at $25^{\circ} \mathrm{C}$. The crude product was recrystallized from hexane, affording white needles, $87 \mathrm{~g}$, $0.25 \mathrm{~mol}$ (47\% yield). ${ }^{1} \mathrm{H} \mathrm{NMR}\left(\mathrm{CDCl}_{3}\right): \delta 4.55\left(\mathrm{~s}, 4 \mathrm{H}, \mathrm{ArCH}_{2^{-}}\right.$ $\mathrm{Br}), 7.25\left(\mathrm{t}, 1 \mathrm{H}, \mathrm{Ar} H,{ }^{3} J=7 \mathrm{~Hz}\right), 7.40\left(\mathrm{~d}, 2 \mathrm{H}, \mathrm{ArH},{ }^{3} J=7 \mathrm{~Hz}\right.$ ).

2-Bromo-1,3-bis[(dimethylamino)methyl]benzene (1a). This synthesis is a slightly modified version of a literature procedure.,12 To a stirred solution of $\mathrm{Me}_{2} \mathrm{NH}(40 \mathrm{~mL}, 27.2 \mathrm{~g}, 0.6$ $\mathrm{mol})$ in $\mathrm{C}_{6} \mathrm{H}_{6}(100 \mathrm{~mL})$ at $6{ }^{\circ} \mathrm{C}$ was added dropwise a solution of 2-bromo-1,3-bis(bromomethyl) benzene $(40 \mathrm{~g}, 0.12 \mathrm{~mol}$ ) dissolved in $\mathrm{C}_{6} \mathrm{H}_{6}(200 \mathrm{~mL})$ in $1 \mathrm{~h}$. The reaction mixture was then stirred for an additional $2 \mathrm{~h}$. Subsequently, the white solid ([Me $\mathrm{Me}_{2}$ $\left.\mathrm{NH}_{2}\right]^{+} \mathrm{Br}$ ) in the reaction mixture was removed by filtration over a G4 glass frit. The filtrate was concentrated by rotary evaporation to afford a yellow oil which was purified by flash distillation $\left( \pm 100^{\circ} \mathrm{C}, 0.05 \mathrm{mmHg}\right)$ and collected in a vessel cooled with liquid nitrogen, affording a colorless oil, $27.5 \mathrm{~g}, 101 \mathrm{mmol}$ (87\% yield). ${ }^{1} \mathrm{H}$ NMR $\left(\mathrm{CDCl}_{3}\right): \delta 2.28\left(\mathrm{~s}, 12 \mathrm{H}, \mathrm{NCH}_{3}\right), 3.52(\mathrm{~s}$, $4 \mathrm{H}, \mathrm{ArCH}_{2}$ ), $7.20\left(\mathrm{t}, 1 \mathrm{H}, \mathrm{ArH},{ }^{3} J=7 \mathrm{~Hz}\right), 7.30$ (d, $2 \mathrm{H}, \operatorname{Ar} H$, $\left.{ }^{3} J=7 \mathrm{~Hz}\right),{ }^{13} \mathrm{C} \mathrm{NMR}\left(\mathrm{CDCl}_{3}\right): \delta 45.61\left(\mathrm{NCH}_{3}\right), 63.98\left(\mathrm{ArCH}_{2}\right)$, 126.60 and 129.41 ( $\{\mathrm{Ar}\} \mathrm{CH}), 126.96(\{\mathrm{Ar}\} \mathrm{CBr}), 138.69$ (\{Ar\}$\mathrm{CCH}_{2} \mathrm{~N}$ ).

2-Bromo-1,3-bis[(dimethylamino)methyl]-5-nitrobenzene (1b). 2-Bromo-1,3-bis[(dimethylamino)methyl] benzene $\left(20.0 \mathrm{~g}, 73.7 \mathrm{mmol}\right.$ ) was added dropwise to concentrated $\mathrm{H}_{2} \mathrm{SO}_{4}$ $(60 \mathrm{~mL})$ at $0^{\circ} \mathrm{C}$. Subsequently, $100 \% \mathrm{HNO}_{3}(10 \mathrm{~mL})$ was added dropwise, while the temperature of the reaction mixture was maintained below $10^{\circ} \mathrm{C}$. After the reaction mixture was stirred at room temperature for an additional $3 \mathrm{~h}$, the reaction mixture was poured into $100 \mathrm{~mL}$ of $\mathrm{H}_{2} \mathrm{O}$ and $400 \mathrm{~g}$ of crushed ice. Upon careful addition of powdered $\mathrm{KOH}$ followed by $\mathrm{K}_{2} \mathrm{CO}_{3}$ the reaction mixture was brought to $\mathrm{pH} 8$. A white solid was filtered off $\left(\mathrm{K}_{2} \mathrm{SO}_{4}\right.$ and $\left.\mathrm{KNO}_{3}\right)$ and extracted with $\mathrm{CH}_{2} \mathrm{Cl}_{2}(2 \times 100 \mathrm{~mL})$. 
The aqueous filtrate was extracted with $\mathrm{CH}_{2} \mathrm{Cl}_{2}(4 \times 200 \mathrm{~mL})$, The combined organic extracts were dried over $\mathrm{MgSO}_{4}$ and concentrated by rotary evaporation, affording a yellow solid, 21.7 $\mathrm{g}, 68.6 \mathrm{mmol}$ (93\% yield). ${ }^{1} \mathrm{H} \mathrm{NMR}\left(\mathrm{CDCl}_{3}\right): \delta 2.29(\mathrm{~s}, 12 \mathrm{H}$, $\left.\mathrm{NCH}_{3}\right), 3.54\left(\mathrm{~s}, 4 \mathrm{H}, \mathrm{ArCH}{ }_{2}\right), 8.28(\mathrm{~s}, 2 \mathrm{H}, \mathrm{Ar} H) .{ }^{13} \mathrm{C}$ NMR $\left(\mathrm{CDCl}_{3}\right): \delta 45.66\left(\mathrm{NCH}_{3}\right), 63.44\left(\mathrm{ArCH}_{2}\right), 123.30(\{\mathrm{Ar}\} \mathrm{CH}), 132.95$ (\{Ar\}CBr), $141.11\left(\{\mathrm{Ar}\} \mathrm{CCH}_{2} \mathrm{~N}\right), 147.18\left(\{\mathrm{Ar}\} \mathrm{CNO}_{2}\right)$.

5-Amino-2-bromo-1,3-bis[(dimethylamino)methyl]benzene (1c). To a stirred solution of 2-bromo-1,3-bis [(dimethy]amino)methyl]-5-nitrobenzene $(20 \mathrm{~g}, 63.3 \mathrm{mmol})$ in dry EtOH $(250 \mathrm{~mL}$ ) was added a carbon-supported noble-metal hydrogenation catalyst $(5 \% \mathrm{Ru} / \mathrm{C}, 2.0 \mathrm{~g}$ or $10 \% \mathrm{Pt} / \mathrm{C}, 1.0 \mathrm{~g})$. The reaction mixture was heated to $50^{\circ} \mathrm{C}$. At this temperature hydrazine monohydrate $(40 \mathrm{~mL})$ was added dropwise and the reaction mixture was subsequently boiled for $2 \mathrm{~h}$. The catalyst was filtered off (a G4 glass frit with a layer of infusorial earth) and the filtrate was concentrated by rotary evaporation. The resulting oil was dissolved in $\mathrm{CH}_{2} \mathrm{Cl}_{2}(100 \mathrm{~mL})$ and washed twice with $\mathrm{H}_{2} \mathrm{O}(100$ $\mathrm{mL}$ ). The organic layer was dried over $\mathrm{MgSO}_{4}$ and concentrated by rotary evaporation, affording a light yellow solid, $15.5 \mathrm{~g}, 54.2$ mmol (86\% yield). ${ }^{1} \mathrm{H}$ NMR $\left(\mathrm{CDCl}_{3}\right): \delta 2.29\left(\mathrm{~s}, 12 \mathrm{H}, \mathrm{NCH}_{3}\right)$, 3.45 (s, $4 \mathrm{H}, \mathrm{ArCH}_{2}$ ), 3.68 (br s, $2 \mathrm{H}, \mathrm{NH}_{2}$ ), 6.70 (s, $2 \mathrm{H}, \mathrm{ArH}$ ). ${ }^{13} \mathrm{C} \mathrm{NMR}\left(\mathrm{CDCl}_{3}\right): \delta 45.96\left(\mathrm{NCH}_{3}\right), 64.06\left(\mathrm{ArCH}_{2}\right), 114.88(\{\mathrm{Ar}\}-$ $\mathrm{CBr}), 116.26(\{\mathrm{Ar}\} \mathrm{CH}), 139.41\left(\{\mathrm{Ar}\} \mathrm{CCH}_{2} \mathrm{~N}\right), 145.62\left(\{\mathrm{Ar}\} \mathrm{CNH}_{2}\right)$.

5-(Acetylamino)-2-bromo-1,3-bis[(dimethylamino)methyl]benzene (1d). To a stirred solution of acetyl chloride (1.1 $\mathrm{mL})$ and an excess of $\mathrm{Et}_{3} \mathrm{~N}(6 \mathrm{~mL})$ in $\mathrm{CH}_{2} \mathrm{Cl}_{2}(30 \mathrm{~mL})$ was added dropwise a solution of 5-amino-2-bromo-1,3-bis [(dimethylamino)methyl] benzene $(4 \mathrm{~g}, 14 \mathrm{mmol})$ in $\mathrm{CH}_{2} \mathrm{Cl}_{2}(20 \mathrm{~mL})$ while the reaction temperature was maintained at $25^{\circ} \mathrm{C}$. Subsequently, the reaction mixture was stirred for $16 \mathrm{~h}$. After the precipitate had been filtered off, the filtrate was washed with $\mathrm{H}_{2} \mathrm{O}$, until the aqueous washings had a $\mathrm{pH}$ of 7 . The organic layer was dried over $\mathrm{MgSO}_{4}$ and concentrated by rotary evaporation, affording a light yellow solid, $4.1 \mathrm{~g}, 12.6 \mathrm{mmol}$ ( $89 \%$ yield). ${ }^{1} \mathrm{H}$ NMR $\left(\mathrm{CDCl}_{3}\right): \delta 2.14\left(\mathrm{~s}, 3 \mathrm{H}, \mathrm{CH}_{3} \mathrm{C}(\mathrm{O})\right), 2.29\left(\mathrm{~s}, 12 \mathrm{H}, \mathrm{NCH}_{3}\right) 3.51 \mathrm{(s}$, $\left.4 \mathrm{H}, \mathrm{ArCH}_{2}\right) 7.48$ (br s, $\left.2 \mathrm{H}, \mathrm{NH}\right), 7.52$ (s, $2 \mathrm{H}, \mathrm{ArH}$ ). ${ }^{13} \mathrm{C} \mathrm{NMR}$ $\left(\mathrm{CDCl}_{3}\right): \delta 24.02\left(\mathrm{CH}_{3} \mathrm{C}(\mathrm{O})\right), 45.70\left(\mathrm{NCH}_{3}\right), 64.61\left(\mathrm{ArCH}_{2}\right), 122.41$ (\{Ar\}CBr), $122.92(\{\mathrm{Ar}\} \mathrm{CH}), 139.08(\{\mathrm{Ar}\} \mathrm{CN}(\mathrm{H})), 139.59$ ( $\{\mathrm{Ar}\}-$ $\left.\mathrm{CCH}_{2} \mathrm{~N}\right), 171.61(\mathrm{C}(\mathrm{O}))$.

2-Bromo-5-chloro-1,3-bis[(dimethylamino)methyl]benzene (1e). To a stirred solution of 5-amino-2-bromo-1,3-bis[(dimethylamino)methyl] benzene $(9 \mathrm{~g}, 31.4 \mathrm{mmol})$ in DMSO (75 $\mathrm{mL}$ ) was added dropwise concentrated $\mathrm{HCl}(37 \%, 15 \mathrm{~mL})$. The reaction mixture was cooled to $0^{\circ} \mathrm{C}$, and subsequently, a mixture of $\mathrm{HCl}(37 \%, 15 \mathrm{~mL})$ and sodium nitrite $(6.1 \mathrm{~g})$ in DMSO (50 $\mathrm{mL}$ ) was added, while the temperature of the reaction mixture was maintained below $10^{\circ} \mathrm{C}$. After this addition 1 equiv of $\mathrm{CuSO}_{4}$ $(7.86 \mathrm{~g}, 31.4 \mathrm{mmol})$ and 0.5 equiv of $\mathrm{CuCl}(1.55 \mathrm{~g}, 15.7 \mathrm{mmol})$ were added. There was immediate gas evolution and the greenish mixture was then stirred for an additional $16 \mathrm{~h}$, while the temperature was slowly raised to room temperature. The reaction mixture was poured into $2 \mathrm{M} \mathrm{NaOH}(400 \mathrm{~mL})$, whereupon the solution changed color from green to blue and then to brown. To the heterogeneous mixture was added $\mathrm{CH}_{2} \mathrm{Cl}_{2}(200 \mathrm{~mL})$, and the whole was filtered (G4 glass frit with a layer of infusorial earth). From the orange filtrate the organic layer was separated and saved; the water layer was again extracted with $\mathrm{CH}_{2} \mathrm{Cl}_{2}(2 \times 100$ $\mathrm{mL})$. The combined organic extracts were dried over $\mathrm{MgSO}_{4}$ and concentrated by rotary evaporation, affording a yellow oil. The crude product was purified by fractional distillation under reduced pressure $\left( \pm 150^{\circ} \mathrm{C}, 0.05 \mathrm{mmHg}\right)$. The first two fractions (DMSO and compound 1a) were discarded; the third fraction gave the yellow oily product, $4.56 \mathrm{~g}, 14.9 \mathrm{mmol}$ (47\% yield). ${ }^{1} \mathrm{H}$ $\operatorname{NMR}\left(\mathrm{CDCl}_{3}\right): \delta 2.29\left(\mathrm{~s}, 12 \mathrm{H}, \mathrm{NCH}_{3}\right), 3.49\left(\mathrm{~s}, 4 \mathrm{H}, \mathrm{ArCH}{ }_{2}\right), 3.68$ (br s, $\left.2 \mathrm{H}, \mathrm{NH}_{2}\right), 7.36(\mathrm{~s}, 2 \mathrm{H}, \mathrm{ArH}) .{ }^{13} \mathrm{C} \mathrm{NMR}\left(\mathrm{CDCl}_{3}\right): \delta 45.67$ $\left.\left(\mathrm{NCH}_{3}\right), 63.53(\mathrm{ArCH})_{2}\right), 124.19(\{\mathrm{Ar}\} \mathrm{CBr}), 128.89(\{\mathrm{Ar}\} \mathrm{CH}), 133.23$ ( $\{\mathrm{Ar}\} \mathrm{CCl}), 140.52\left(\{\mathrm{Ar}\} \mathrm{CCH}_{2} \mathrm{~N}\right)$.

$\boldsymbol{N}$-Benzylidene-4-bromo-3,5-bis[(dimethylamino)methyl]aniline (1f). To a stirred solution of 4-amino-1-bromo-2,6-bis[(dimethylamino)methyl] benzene $(3.42 \mathrm{~g}, 11.9 \mathrm{mmol})$ and $\mathrm{Na}_{2} \mathrm{SO}_{4}$ in benzene $(50 \mathrm{~mL})$ was added dropwise a solution of benzal- dehyde ( $1.45 \mathrm{~g}, 13.7 \mathrm{mmol}$ ) in benzene ( $30 \mathrm{~mL}$ ). Subsequently, a catalytic amount of formic acid was added and the reaction mixture was stirred for an additional $16 \mathrm{~h}$. The solution was filtered (G4 glass frit) and the volatiles were removed from the filtrate in vacuo, affording a yellow oil, $3.91 \mathrm{~g}, 10.4 \mathrm{mmol}(87.4 \%$ yield). ${ }^{1} \mathrm{H} \mathrm{NMR}\left(\mathrm{CDCl}_{3}\right): \delta 2.40\left(\mathrm{~s}, 12 \mathrm{H}, \mathrm{NCH}_{3}\right), 3.65(\mathrm{~s}, 4 \mathrm{H}$, $\operatorname{ArCH})_{2}, 7.31(\mathrm{~s}, 2 \mathrm{H}, \operatorname{ArH}), 7.51$ and $7.93(\mathrm{~m}, 5 \mathrm{H}, \mathrm{ArH}), 8.52(\mathrm{~s}$, $1 \mathrm{H}, \mathrm{CHN}) .{ }^{13} \mathrm{C} \mathrm{NMR}\left(\mathrm{CDCl}_{3}\right): \delta 45.70\left(\mathrm{NCH}_{3}\right), 63.93\left(\mathrm{ArCH}_{2}\right)$, 123.96 ( $\{\mathrm{Ar}\} \mathrm{CBr}$ ), 121.77 ( $\{\mathrm{Ar}\} C \mathrm{H}$ meta to $\mathrm{Br}$ ), 128.76 and 128.83, $131.43(\{\mathrm{Ph}\} \mathrm{CH}), 136.14(\{\mathrm{Ph}\} \mathrm{CC}(\mathrm{H}): \mathrm{N}), 139.53\left(\{\mathrm{Ar}\} \mathrm{CCH}_{2} \mathrm{~N}\right)$, 150.71 ( $\{\mathrm{Ar}\} C$ para to $\mathrm{Br}), 160.56(C(\mathrm{H}): \mathrm{N})$.

3,5-Dimethylanisole. To a stirred solution of 3,5-dimethylphenol $(61.5 \mathrm{~g}, 0.50 \mathrm{~mol})$ in DMSO $(500 \mathrm{~mL})$ was added solid $\mathrm{K}_{2} \mathrm{CO}_{3}(207 \mathrm{~g})$ in one portion. After stirring for $30 \mathrm{~min}$, the mixture was cooled with an ice-water bath, and $\mathrm{CH}_{3} \mathrm{I}(31.5 \mathrm{~mL})$ was added dropwise, while the temperature was maintained below $10^{\circ} \mathrm{C}$. Subsequently, the reaction mixture was stirred for $1 \mathrm{~h}$ at $50^{\circ} \mathrm{C}$. After cooling to room temperature, the mixture was poured onto a mixture of ice $(1500 \mathrm{~g})$ and water $(300 \mathrm{~mL})$. The product was isolated by extraction with $\mathrm{Et}_{2} \mathrm{O}(3 \times 500 \mathrm{~mL})$. The combined organic layers were dried over $\mathrm{MgSO}_{4}$ and concentrated by rotary evaporation, affording a light yellow oil, $66.7 \mathrm{~g}, 0.49$ mol (98\% yield). ${ }^{1} \mathrm{H} \mathrm{NMR}\left(\mathrm{CDCl}_{3}\right): \delta 2.35\left(\mathrm{~s}, 6 \mathrm{H}, \mathrm{ArCH} \mathrm{H}_{3}\right), 3.81$ (s, $\left.3 \mathrm{H}, \mathrm{ArOCH}_{3}\right), 6.57(\mathrm{~s}, 2 \mathrm{H}, \mathrm{Ar} H), 6.64(\mathrm{~s}, 1 \mathrm{H}, \mathrm{ArH}) .{ }^{13} \mathrm{C}$ NMR $\left(\mathrm{CDCl}_{3}\right): \delta 21.58\left(\mathrm{ArCH}_{3}\right), 55.21\left(\mathrm{ArOCH}_{3}\right), 111.82$ and 122.59 (\{Ar\}CH), $139.32\left(\{\mathrm{Ar}\} \mathrm{CCH}_{3}\right), 159.79\left(\{\mathrm{Ar}\} \mathrm{COCH}_{3}\right)$.

4-Bromo-3,5-dimethylanisole. To a stirred solution of 3,5dimethylanisole $(60 \mathrm{~g}, 0.44 \mathrm{~mol})$ in glacial acetic acid $(400 \mathrm{~mL})$ was added dropwise a solution of bromine $(70.5 \mathrm{~g})$ in glacial acetic acid $(230 \mathrm{~mL})$, while cooling with an ice-water bath. After the addition was completed the reaction mixture was concentrated to half of its original volume and $4 \mathrm{M} \mathrm{NaOH}(1000 \mathrm{~mL})$ was added to the mixture. The crude organic product (heavy oil) separated and was collected. The water layer was extracted with $\mathrm{Et}_{2} \mathrm{O}(2 \times 300 \mathrm{~mL})$, and the $\mathrm{Et}_{2} \mathrm{O}$ extracts were combined with the organic product. The resulting ethereal solution was dried over $\mathrm{MgSO}_{4}$. Removal of the solvent by rotatory evaporation afforded a yellow oil. Distillation under reduced pressure (105 ${ }^{\circ} \mathrm{C}, 0.01 \mathrm{mmHg}$ ) gave a colorless oil, $76.0 \mathrm{~g}, 0.35 \mathrm{~mol}(80 \%$ yield, purity $95 \%)$. ${ }^{1} \mathrm{H}$ NMR $\left(\mathrm{CDCl}_{3}\right): \delta 2.41\left(\mathrm{~s}, 6 \mathrm{H}, \mathrm{ArCH} \mathrm{H}_{3}\right), 3.79(\mathrm{~s}$, $\left.3 \mathrm{H}, \mathrm{ArOCH} H_{3}\right), 6.67(\mathrm{~s}, 2 \mathrm{H}, \mathrm{ArH}) .{ }^{13} \mathrm{C} \mathrm{NMR}\left(\mathrm{CDCl}_{3}\right): \delta 24.06$ $\left.\left.(\mathrm{ArCH})_{3}\right), 55.30\left(\mathrm{ArOCH}_{3}\right), 113.83(\mathrm{Ar}\} \mathrm{CH}\right), 118.22(\{\mathrm{Ar}\} \mathrm{CBr})$, $139.08\left(\{\mathrm{Ar}\} \mathrm{CCH}_{3}\right), 158.09\left(\{\mathrm{Ar}\} \mathrm{COCH}_{3}\right)$.

4-Bromo-3,5-bis(bromomethyl)anisole. This compound was synthesized according to the procedure for 2-bromo-1,3-bis(bromomethyl)benzene, starting from 4-bromo-3,5-dimethylanisole $(70 \mathrm{~g}, 0.33 \mathrm{~mol})$ and NBS $(117 \mathrm{~g}, 0.66 \mathrm{~mol})$ in $\mathrm{CCl}_{4}(400 \mathrm{~mL})$. Purification of the crude product was slightly modified and was achieved by stirring the crude product in hexane. Subsequent filtration afforded the product as a white solid, $47.9 \mathrm{~g}, 128 \mathrm{mmol}$ ( $39 \%$ yield, purity $>96 \%)$. ${ }^{1} \mathrm{H}$ NMR $\left(\mathrm{CDCl}_{3}\right): \delta 3.79(\mathrm{~s}, 3 \mathrm{H}$, $\left.\mathrm{ArOCH}_{3}\right), 4.58\left(\mathrm{~s}, 4 \mathrm{H}, \mathrm{ArCH} \mathrm{H}_{2} \mathrm{Br}\right), 6.96(\mathrm{~s}, 2 \mathrm{H}, \mathrm{Ar} H) .{ }^{13} \mathrm{C} \mathrm{NMR}$ $\left(\mathrm{CDCl}_{3}\right): \delta 34.16\left(\mathrm{ArCH}{ }_{2} \mathrm{Br}\right), 55.94\left(\mathrm{ArOCH}_{3}\right), 117.05(\{\mathrm{Ar}\} \mathrm{CBr})$, $117.26(\{\mathrm{Ar}\} \mathrm{CH}), 139.42\left(\{\mathrm{Ar}\} \mathrm{CCH}_{2} \mathrm{Br}\right), 159.01\left(\{\mathrm{Ar}\} \mathrm{COCH}_{3}\right)$.

4-Bromo-3,5-bis[(dimethylamino)methyl]anisole (1g). This compound was synthesized according to the procedure for 2-bromo-1,3-bis[(dimethylamino)methyl] benzene, starting from 4-bromo-3,5-bis(bromomethyl)anisole $\left(12 \mathrm{~g}, 32.2 \mathrm{mmol}\right.$ ) in $\mathrm{C}_{6} \mathrm{H}_{6}$ $(75 \mathrm{~mL})$ and $\mathrm{Me}_{2} \mathrm{NH}(11 \mathrm{~mL}, 7.5 \mathrm{~g}, 0.16 \mathrm{~mol})$ in $\mathrm{C}_{6} \mathrm{H}_{6}(100 \mathrm{~mL})$. The product is obtained as a yellow oil, $8.4 \mathrm{~g}, 27.9 \mathrm{mmol}(88 \%$ yield). ${ }^{1} \mathrm{H}$ NMR $\left(\mathrm{CDCl}_{3}\right): \delta 2.25\left(\mathrm{~s}, 12 \mathrm{H}, \mathrm{NCH}_{3}\right), 3.46(\mathrm{~s}, 4 \mathrm{H}$, $\left.\mathrm{ArCH}_{2} \mathrm{~N}\right), 3.75\left(\mathrm{~s}, 3 \mathrm{H}, \mathrm{ArOCH}_{3}\right), 6.88(\mathrm{~s}, 2 \mathrm{H}, \mathrm{ArH}) .{ }^{13} \mathrm{C}$ NMR $\left(\mathrm{CDCl}_{3}\right): \delta 45.6\left(\mathrm{NCH}_{3}\right), 55.5\left(\mathrm{ArOCH}_{3}\right), 63.8\left(\mathrm{ArCH}_{2}\right), 114.9(\{\mathrm{Ar}\}-$ $\mathrm{CH}), 117.1(\{\mathrm{Ar}\} \mathrm{CBr}), 139.5\left(\{\mathrm{Ar}\} \mathrm{CCH}_{2} \mathrm{~N}\right), 158.5\left(\{\mathrm{Ar}\} \mathrm{COCH}_{3}\right)$.

4-Bromo-3,5-dimethylacetophenone. To a stirred heterogeneous mixture of $\mathrm{AlCl}_{3}(77 \mathrm{~g}, 0.58 \mathrm{~mol})$ and carbon tetrachloride ( $400 \mathrm{~mL}$ ), cooled to $5^{\circ} \mathrm{C}$, was added dropwise acetyl chloride (44 $\mathrm{mL}, 0.62 \mathrm{~mol}$ ). This addition was followed by the dropwise addition of 2-bromo- $m$-xylene $(80 \mathrm{~g}, 0.43 \mathrm{~mol})$ at $10-15^{\circ} \mathrm{C}$. The reaction mixture was stirred at room temperature for $24 \mathrm{~h}$. Afterward the reaction mixture was poured into a mixture of ice $(800 \mathrm{~g})$ and concentrated $\mathrm{HCl}(37 \%, 120 \mathrm{~mL})$. The organic layer 
was separated and washed twice with water $(150 \mathrm{~mL})$, once with $1 \mathrm{M} \mathrm{NaOH}(150 \mathrm{~mL})$, and then again twice with water $(150 \mathrm{~mL})$. The organic layer was dried over $\mathrm{MgSO}_{4}$ and volatiles were removed by rotary evaporation to afford the product as a brown oil. Purification by crystallization from hexane afforded $a$ white crystalline solid, $51.3 \mathrm{~g}, 0.23 \mathrm{~mol}\left(52 \%\right.$ yield). ${ }^{1} \mathrm{H} \mathrm{NMR}\left(\mathrm{CDCl}_{3}\right)$ : $\delta 2.47\left(\mathrm{~s}, 6 \mathrm{H}, \mathrm{ArCH}_{3}\right), 2.54\left(\mathrm{~s}, 3 \mathrm{H}, \mathrm{C}(\mathrm{O}) \mathrm{CH}_{3}\right), 7.63$ (s, $\left.2 \mathrm{H}, \mathrm{ArH}\right)$.

4-Bromo-3,5-bis(bromomethyl)acetophenone. This compound was synthesized according to the procedure for 2-bromo1,3-bis(bromomethyl)benzene, starting from 4-bromo-3,5-dimethylacetophenone $(50 \mathrm{~g}, 0.22 \mathrm{~mol})$ and NBS $(86 \mathrm{~g}, 0.48 \mathrm{~mol})$ in $\mathrm{CCl}_{4}(700 \mathrm{~mL})$. However, the purification procedure employed was different. The crude product was stirred in a 1:9 mixture of $\mathrm{CHCl}_{3}$ :hexane, and subsequent filtration afforded a white solid that was further purified by recrystallization from a 1:2 mixture of $\mathrm{CHCl}_{3}$ :hexane. The product was obtained as a white crystalline solid, $45 \mathrm{~g}, 0.12 \mathrm{~mol}\left(53 \%\right.$ yield). ${ }^{1} \mathrm{H} \mathrm{NMR}\left(\mathrm{CDCl}_{3}\right): \delta 2.62$ (s, $\left.3 \mathrm{H}, \mathrm{C}(\mathrm{O}) \mathrm{CH}_{3}\right), 4.68\left(\mathrm{~s}, 4 \mathrm{H}, \mathrm{ArCH} \mathrm{H}_{2} \mathrm{Br}\right), 7.96(\mathrm{~s}, 2 \mathrm{H}, \mathrm{ArH}) \cdot{ }^{23} \mathrm{C}$ $\mathrm{NMR}\left(\mathrm{CDCl}_{3}\right): \delta 26.63\left(\mathrm{C}(\mathrm{O}) \mathrm{CH}_{3}\right), 33.23\left(\mathrm{ArCH} \mathrm{H}_{2} \mathrm{Br}\right), 130.60(\{\mathrm{Ar}\}-$ $\mathrm{CH}), 131.85$ ( $\{\mathrm{Ar}\} \mathrm{CBr}), 136.56\left(\{\mathrm{Ar}\} \mathrm{CC}(\mathrm{O}) \mathrm{CH}_{3}\right), 139.19\left(\{\mathrm{Ar}\} \mathrm{CCH}_{2}\right.$ $\mathrm{Br}), 196.02\left(\mathrm{C}(\mathrm{O}) \mathrm{CH}_{3}\right)$.

4-Bromo-3,5-bis[(dimethylamino)methyl]acetophenone (1h). This compound was synthesized according to the procedure for 2-bromo-1,3-bis [(dimethylamino)methyl]benzene, starting from 4-bromo-3,5-bis(bromomethyl)acetophenone $(20 \mathrm{~g}, 52 \mathrm{mmol})$ in $\mathrm{C}_{6} \mathrm{H}_{6}(200 \mathrm{~mL})$ and $\mathrm{Me}_{2} \mathrm{NH}(17 \mathrm{~mL}, 11.6 \mathrm{~g}, 0.26 \mathrm{~mol})$ in $\mathrm{C}_{6} \mathrm{H}_{6}$ $(100 \mathrm{~mL})$. The product was obtained as a pale yellow oil, which solidified upon standing, $15.2 \mathrm{~g}, 48.5 \mathrm{mmol}$ (93\% yield). ${ }^{1} \mathrm{H} \mathrm{NMR}$ $\left(\mathrm{CDCl}_{3}\right): \delta 2.30\left(\mathrm{~s}, 12 \mathrm{H}, \mathrm{NCH}_{3}\right), 2.59\left(\mathrm{~s}, 3 \mathrm{H}, \mathrm{C}(\mathrm{O}) \mathrm{CH}_{3}\right), 3.56$ (s, $\left.4 \mathrm{H}, \mathrm{ArCH}_{2} \mathrm{~N}\right), 7.88(\mathrm{~s}, 2 \mathrm{H}, \mathrm{ArH}) .{ }^{13} \mathrm{C} \mathrm{NMR}\left(\mathrm{CDCl}_{3}\right): \delta 26.77$ $\left(\mathrm{C}(\mathrm{O}) \mathrm{CH}_{3}\right), 45.59\left(\mathrm{NCH}_{3}\right), 63.77\left(\mathrm{ArCH}_{2} \mathrm{~N}\right), 128.88(\{\mathrm{Ar}\} \mathrm{CH})$, $132.41(\{\mathrm{Ar}\} \mathrm{CBr}), 135.56\left(\{\mathrm{Ar}\} \mathrm{CC}(\mathrm{O}) \mathrm{CH}_{3}\right), 139.44\left(\{\mathrm{Ar}\} \mathrm{CCH}_{2} \mathrm{~N}\right)$, $197.77\left(\mathrm{C}(\mathrm{O}) \mathrm{CH}_{3}\right)$.

Organonickel(II) Complexes. [ $\mathrm{Ni}\left\{\mathrm{C}_{6} \mathrm{H}_{3}\left(\mathrm{CH}_{2} \mathrm{NMe}_{2}\right)_{2-2,6\}-}\right.$ Br] (2a). The synthesis is a modification of a literature procedure. ${ }^{4}$ To a stirred solution of $\mathrm{Ni}(\mathrm{COD})_{2}(9.0 \mathrm{~g}, 33 \mathrm{mmol})$ in THF $(100 \mathrm{~mL})$ at $-78^{\circ} \mathrm{C}$ was added dropwise a solution of 2-bromo-1,3-bis [(dimethylamino)methyl] benzene (1a) (9.2 g, 34 $\mathrm{mmol})$ in THF ( $100 \mathrm{~mL})$. After the addition the temperature of the reaction mixture was slowly raised over a period of $2 \mathrm{~h}$ to room temperature. During this period the mixture changed in color from yellow through green to finally orange-brown. After stirring for $2 \mathrm{~h}$ at room temperature the solution was filtered over a G4 glass frit and concentrated in vacuo. Cycloocta-1,5diene was removed by washing the crude product with cold hexane $\left(-30^{\circ} \mathrm{C}\right)$. Crystallization of the product was accomplished by dissolving it in a minimum of $\mathrm{MeOH}$ at $35^{\circ} \mathrm{C}$, filtering, and cooling to $-30^{\circ} \mathrm{C}$. The orange, hairlike crystals were collected by filtration and dried in vacuo, $9.1 \mathrm{~g}, 27.7 \mathrm{mmol}$ ( $84 \%$ yield). ${ }^{1} \mathrm{H}$ NMR $\left(\mathrm{CD}_{3} \mathrm{OD}\right): \delta 2.64\left(\mathrm{~s}, 12 \mathrm{H}, \mathrm{NCH}_{3}\right), 3.70\left(\mathrm{~s}, 4 \mathrm{H}, \mathrm{ArCH}_{2}\right)$, $6.60(\mathrm{~d}, 2 \mathrm{H}, \mathrm{ArH}), 6.92(\mathrm{t}, 1 \mathrm{H}, \mathrm{ArH}) .{ }^{13} \mathrm{C} \mathrm{NMR}\left(\mathrm{CD}_{3} \mathrm{OD}\right): \delta$ $\left.51.79\left(\mathrm{NCH}_{3}\right), 74.04(\mathrm{ArCH})_{2}\right), 119.82(2 \mathrm{C},\{\mathrm{Ar}\} \mathrm{CH}), 126.29(1 \mathrm{C}$, $\{\mathrm{Ar}\} \mathrm{CH}, 148.16\left(\{\mathrm{Ar}\} \mathrm{CCH}_{2} \mathrm{~N}\right), 150.38(\{\mathrm{Ar}\} \mathrm{CNi}) . \mathrm{FAB} / \mathrm{MS}(\mathrm{m} /$ $z): 328\left(\mathrm{M}^{\bullet+}\right), 249\left(\mathrm{M}-\mathrm{Br}^{+}\right)$. Anal. Calcd for $\mathrm{C}_{12} \mathrm{H}_{19} \mathrm{BrN}_{2} \mathrm{Ni}$ : C, $43.69 ; \mathrm{H}, 5.81 ; \mathrm{N}, 8.49$. Found: C, $43.27 ; \mathrm{H}, 5.67 ; \mathrm{N}, 8.35$.

[Ni\{4- $\left.\left.\mathrm{NH}_{2} \mathrm{C}_{6} \mathrm{H}_{2}\left(\mathrm{CH}_{2} \mathrm{NMe}_{2}\right)_{2}-2,6\right\} \mathrm{Br}\right]$ (2c). Complex 2c was synthesized according to the procedure for $\left[\mathrm{Ni}\left\{\mathrm{C}_{6} \mathrm{H}_{3}\left(\mathrm{CH}_{2} \mathrm{NMe}_{2}\right)_{2-}\right.\right.$ 2,6\}Br], starting from 5-amino-2-bromo-1,3-bis [(dimethylamino)methyl] benzene (1c) $(5.0 \mathrm{~g}, 17.5 \mathrm{mmol})$ in THF $(60 \mathrm{~mL})$ and $\mathrm{Ni}(\mathrm{COD})_{2}(4.5 \mathrm{~g}, 16.4 \mathrm{mmol})$ in THF $(70 \mathrm{~mL})$. At $21^{\circ} \mathrm{C}$ the reaction mixture changed from yellow to orange-brown. Since the product is particularly air-sensitive, the isolation of the product was slightly different from that described for $2 \mathrm{a}$. After the crude product had been washed with hexane, it was redissolved in acetone and filtered over a G4 glass frit and the volatiles were removed in vacuo. Stirring the solid residue in cold $\mathrm{MeOH}$ gave the orange product which was collected by filtration, $0.7 \mathrm{~g}, 2.0$ mmol ( $11 \%$ yield). ${ }^{1} \mathrm{H}$ NMR $\left(\mathrm{CD}_{3} \mathrm{OD}\right): \delta 2.51\left(\mathrm{~s}, 12 \mathrm{H}, \mathrm{NCH}_{3}\right)$ 3.62 (s, $\left.4 \mathrm{H}, \mathrm{ArCH}_{2}\right), 6.12$ (s, $2 \mathrm{H}, \mathrm{Ar} H$ ), $\mathrm{NH}_{2}$ not observed. ${ }^{13} \mathrm{C}$ NMR $\left(\mathrm{CD}_{3} \mathrm{OD}\right): \delta 51.57\left(\mathrm{NCH}_{3}\right), 73.96\left(\mathrm{ArCH}_{2}\right), 136.0(\{\mathrm{Ar}\}-$ $C \mathrm{Ni}), 108.38(\{\mathrm{Ar}\} \mathrm{CH}), 148.52\left(\{\mathrm{Ar}\} \mathrm{CCH}_{2} \mathrm{~N}\right), 146.88\left(\{\mathrm{Ar}\} C \mathrm{NH}_{2}\right)$. FAB/MS $(m / z): 343\left(\mathrm{M}^{\circ+}\right), 264\left(\mathrm{M}-\mathrm{Br}^{+}\right)$. Anal. Calcd for
$\mathrm{C}_{12} \mathrm{H}_{20} \mathrm{BrN}_{3} \mathrm{Ni}: \mathrm{C}, 41.79 ; \mathrm{H}, 5.84 ; \mathrm{N}, 12.18$. Found: $\mathrm{C}, 41.73 ; \mathrm{H}$, $5.86 ; \mathrm{N}, 11.92$.

[Ni\{4-MeC(O)N(H) $\left.\left.\mathrm{C}_{6} \mathrm{H}_{2}\left(\mathrm{CH}_{2} \mathrm{NMe}_{2}\right)_{2}-2,6\right\} \mathrm{Br}\right]$ (2d). Complex $2 \mathrm{~d}$ was synthesized according to the procedure for [Ni$\left.\left\{\mathrm{C}_{6} \mathrm{H}_{3}\left(\mathrm{CH}_{2} \mathrm{Me}_{2}\right)_{2}-2,6\right\} \mathrm{Br}\right]$, starting from 5-(acetylamino)-2-bromo1,3-bis[(dimethylamino)methyl]benzene (1d) $(2.5 \mathrm{~g}, 7.6 \mathrm{mmol})$ in THF $(50 \mathrm{~mL})$ and $\mathrm{Ni}(\mathrm{COD})_{2}(2.0 \mathrm{~g}, 7.3 \mathrm{mmol})$ in THF $(50 \mathrm{~mL})$. The reaction mixture turned dark orange at $0^{\circ} \mathrm{C}$. Volatiles were removed in vacuo. The residue, a dark brown solid, was dissolved in $\mathrm{CH}_{2} \mathrm{Cl}_{2}$ and precipitated in hexane. The orange product was isolated by filtration, $2.0 \mathrm{~g}, 5.2 \mathrm{mmol}\left(70 \%\right.$ yield). ${ }^{1} \mathrm{H}$ NMR ( $\left.\mathrm{CD}_{3} \mathrm{OD}\right): \delta 2.08\left(\mathrm{~s}, 3 \mathrm{H}, \mathrm{CH}_{3} \mathrm{C}(\mathrm{O})\right), 2.65\left(\mathrm{~s}, 12 \mathrm{H}, \mathrm{NCH}_{3}\right), 3.70$ (s, $\left.4 \mathrm{H}, \mathrm{ArCH}{ }_{2}\right), 6.81$ (s, $\left.2 \mathrm{H}, \mathrm{ArH}\right) .{ }^{13} \mathrm{C} \mathrm{NMR}\left(\mathrm{CD}_{3} \mathrm{OD}\right): \delta 23.67$ $\left(\mathrm{CH}_{3} \mathrm{C}(\mathrm{O})\right), 51.53\left(\mathrm{NCH}_{3}\right), 73.90\left(\mathrm{ArCH} \mathrm{H}_{2}\right), 112.68(\{\mathrm{Ar}\} \mathrm{CH}), 137.29$ $(\{\operatorname{Ar}\} C N(\mathrm{H})), 144.29(\{\mathrm{Ar}\} C \mathrm{Ni}), 148.20\left(\{\mathrm{Ar}\} \mathrm{CCH}_{2} \mathrm{~N}\right), 171.48$ $\left(C(\mathrm{O})\right.$ ). Anal. Calcd for $\mathrm{C}_{14} \mathrm{H}_{22} \mathrm{BrN}_{3} \mathrm{ONi}$ C, $43.46 ; \mathrm{H}, 5.73 ; \mathrm{N}$, 10.86. Found: C, $43.56 ; \mathrm{H}, 5.72 ; \mathrm{N}, 10.74$.

[Ni $\left\{4-\mathrm{ClC}_{6} \mathrm{H}_{2}\left(\mathrm{CH}_{2} \mathrm{NMe}_{2}\right)_{2}-2,6\right\} \mathrm{Br}$ ] (2e). Complex 2e was synthesized according to the procedure for $\left[\mathrm{Ni}\left\{\mathrm{C}_{6} \mathrm{H}_{3}\left(\mathrm{CH}_{2} \mathrm{NMe}_{2}\right)_{2-}\right.\right.$ $2,6\} \mathrm{Br}$ ], starting from 2-bromo-5-chloro-1,3-bis[(dimethylamino)methyl]benzene (1e) $(2.4 \mathrm{~g}, 7.9 \mathrm{mmol})$ in THF $(50 \mathrm{~mL})$ and $\mathrm{Ni}(\mathrm{COD})_{2}(2.0 \mathrm{~g}, 7.3 \mathrm{mmol})$ in THF $(50 \mathrm{~mL})$. At $-20^{\circ} \mathrm{C}$ the reaction mixture changed from yellow to orange-brown. After crystallization from $\mathrm{MeOH}$ orange, hairlike, crystals were obtained, $1.6 \mathrm{~g}, 4.3 \mathrm{mmol}$ (55\% yield). ${ }^{1} \mathrm{H}$ NMR (CD $\left.{ }_{3} \mathrm{OD}\right): \delta 2.64$ (s, $\left.12 \mathrm{H}, \mathrm{NCH}_{3}\right), 3.69\left(\mathrm{~s}, 4 \mathrm{H}, \mathrm{ArCH} \mathrm{H}_{2}\right), 6.64(\mathrm{~s}, 2 \mathrm{H}, \mathrm{ArH}) .{ }^{13} \mathrm{C}$ NMR (CD $\mathrm{OD}): \delta 51.82\left(\mathrm{NCH}_{3}\right), 73.72\left(\mathrm{ArCH}_{2}\right), 119.95(\{\mathrm{Ar}\}-$ $\mathrm{CH}), 131.85$ ( $(\mathrm{Ar}\} \mathrm{Cl}), 148.35$ ( $\{\mathrm{Ar}\} \mathrm{CNi}), 149.80\left(\{\mathrm{Ar}\} \mathrm{CCH}_{2} \mathrm{~N}\right) . \mathrm{FAB} /$ MS $(m / z): 362\left(\mathbf{M}^{\bullet+}\right), 283\left(\mathbf{M}-\mathrm{Br}^{+}\right)$. Anal. Calcd for $\mathrm{C}_{12} \mathrm{H}_{18} \mathrm{BrClN}_{2} \mathrm{Ni}$ : C, $39.56 ; \mathrm{H}, 4.98 ; \mathrm{N}, 7.69$. Found: C, $39.36 ; \mathrm{H}$, $5.22 ; \mathrm{N}, 7.56$.

[Ni\{4-PhC(H) $\left.\left.\mathrm{NC}_{6} \mathrm{H}_{2}\left(\mathrm{CH}_{2} \mathrm{NMe}_{2}\right)_{2}-2,6\right\} \mathrm{Br}\right](2 \mathrm{f})$. Complex $2 \mathrm{f}$ was synthesized according to the procedure for $\left[\mathrm{Ni}\left\{\mathrm{C}_{6} \mathrm{H}_{3}\left(\mathrm{CH}_{2}\right.\right.\right.$ $\left.\left.\mathrm{NMe}_{2}\right)_{2}-2,6\right\} \mathrm{Br}$ ], starting with $N$-benzylidene-4-bromo-3,5-bis[(dimethylamino)methyl]aniline (1f) $(1.5 \mathrm{~g}, 4.0 \mathrm{mmol})$ in THF $(40 \mathrm{~mL})$ and $\mathrm{Ni}(\mathrm{COD})_{2}(1.0 \mathrm{~g}, 3.6 \mathrm{mmol})$ in THF $(40 \mathrm{~mL})$. At $-18^{\circ} \mathrm{C}$ the reaction mixture turned dark orange-brown. After crystallization from $\mathrm{MeOH}$ orange, hairlike crystals were obtained, $1.3 \mathrm{~g}, 3.1 \mathrm{mmol}$ (76\% yield). ${ }^{1} \mathrm{H}$ NMR $\left(\mathrm{CD}_{3} \mathrm{OD}\right): \delta 2.68$ (s, $\left.12 \mathrm{H}, \mathrm{NCH}_{3}\right), 3.77\left(\mathrm{~s}, 4 \mathrm{H}, \mathrm{CH}_{2}\right), 6.61(\mathrm{~s}, 2 \mathrm{H}, \mathrm{ArH}), 7.46$ and $7.84(\mathrm{~m}, 5 \mathrm{H}, \mathrm{Ar} H), 8.51$ (HCN). ${ }^{13} \mathrm{C}$ NMR $\left(\mathrm{CD}_{3} \mathrm{OD}\right): \delta 51.62$ $\left.\left(\mathrm{NCH}_{3}\right), 73.94(\mathrm{ArCH})_{2}\right), 112.94(\{\mathrm{Ar}\} \mathrm{CH}), 129.7,129.86$, and 132.4 (\{Ar\}CH), 137.66 (\{Ar\}CCN), 148.09 (\{Ar\}CNi), 148.95 (\{Ar\}$\left.\mathrm{CCH}_{2} \mathrm{~N}\right), 151.25$ ( $\left.(\mathrm{Ar}\} \mathrm{CNC}\right), 161.11(\mathrm{CHN})$. Anal. Calcd for $\mathrm{C}_{19} \mathrm{H}_{24} \mathrm{BrN}_{3} \mathrm{Ni}$ : C, $52.70 ; \mathrm{H}, 5.59 ; \mathrm{N}, 9.70$. Found: $\mathrm{C}, 52.58 ; \mathrm{H}$, $5.57 ; \mathrm{N}, 9.78$.

[Ni\{4-MeOC $\left.\left.{ }_{6} \mathrm{H}_{2}\left(\mathrm{CH}_{2} \mathrm{NMe}_{2}\right)_{2}-2,6\right\} \mathrm{Br}\right](2 \mathrm{~g})$. Complex $2 \mathrm{~g}$ was synthesized according to the procedure for $\left[\mathrm{Ni}\left\{\mathrm{C}_{6} \mathrm{H}_{3}\left(\mathrm{CH}_{2} \mathrm{NMe}_{2}\right)_{2-}\right.\right.$ $2,6\} \mathrm{Br}$ ], starting from 4-bromo-3,5-bis [(dimethylamino)methyl]anisole $(1 \mathrm{~g})(8.0 \mathrm{~g}, 26.6 \mathrm{mmol})$ in THF $(90 \mathrm{~mL})$ and $\mathrm{Ni}(\mathrm{COD})_{2}$ $(6.6 \mathrm{~g}, 24 \mathrm{mmol})$ in $\mathrm{THF}(80 \mathrm{~mL})$. At $10^{\circ} \mathrm{C}$ the reaction mixture changed from yellow to green and subsequently to orange-brown. After crystallization from $\mathrm{MeOH}$ orange, platelike crystals were obtained, $3.1 \mathrm{~g}, 8.6 \mathrm{mmol}$ ( $33 \%$ yield). ${ }^{\mathrm{1}} \mathrm{H}$ NMR $\left(\mathrm{CD}_{3} \mathrm{OD}\right): \delta$ $2.73\left(\mathrm{~s}, 12 \mathrm{H}, \mathrm{NCH}_{3}\right), 3.65\left(\mathrm{~s}, 3 \mathrm{H}, \mathrm{ArOCH}_{3}\right), 3.76\left(\mathrm{~s}, 4 \mathrm{H}, \mathrm{ArCH}_{2} \mathrm{~N}\right)$, $6.23(\mathrm{~s}, 2 \mathrm{H}, \mathrm{ArH}) .{ }^{13} \mathrm{C} \mathrm{NMR}\left(\mathrm{CD}_{3} \mathrm{OD}\right): \delta 51.87\left(\mathrm{NCH}_{3}\right), 55.12$ $\left.\left(\mathrm{ArOCH} \mathrm{H}_{3}\right), 74.12(\mathrm{ArCH})_{2}\right), 106.34(\{\mathrm{Ar}\} \mathrm{CH}), 139.17(\{\mathrm{Ar}\} C \mathrm{Ni})$, $148.8\left(\{\mathrm{Ar}\} \mathrm{CCH}_{2} \mathrm{~N}\right), 160.56\left(\{\mathrm{Ar}\} \mathrm{COCH}_{3}\right) . \mathrm{FAB} / \mathrm{MS}(\mathrm{m} / \mathrm{z}): 358$ $\left(\mathrm{M}^{*+}\right), 279\left(\mathrm{M}-\mathrm{Br}^{+}\right)$. Anal. Calcd for $\mathrm{C}_{13} \mathrm{H}_{21} \mathrm{BrN}_{2} \mathrm{ONi}$ : C, 43.38; $\mathrm{H}, 5.88 ; \mathrm{N}, 7.78 ; \mathrm{O}, 4.45$. Found: $\mathrm{C}, 43.42 ; \mathrm{H}, 5.93 ; \mathrm{N}, 7.75 ; \mathrm{O}$, 4.42 .

[Ni\{4-MeC(O) $\left.\left.\mathrm{C}_{6} \mathrm{H}_{2}\left(\mathrm{CH}_{2} \mathrm{NMe}_{2}\right)_{2}-2,6\right\} \mathrm{Br}\right](2 \mathrm{~h})$. Complex $2 \mathrm{~h}$ was synthesized according to the procedure for $\left[\mathrm{Ni}\left\{\mathrm{C}_{6} \mathrm{H}_{3}\left(\mathrm{CH}_{2}-\right.\right.\right.$ $\left.\left.\mathrm{NMe}_{2}\right)_{2}-2,6\right\} \mathrm{Br}$, starting from 4-bromo-3,5-bis [(dimethylamino)methyl]acetophenone $(1 \mathrm{~h})(5.5 \mathrm{~g}, 17.6 \mathrm{mmol})$ in THF $(70 \mathrm{~mL})$ and $\mathrm{Ni}(\mathrm{COD})_{2}(4.4 \mathrm{~g}, 16 \mathrm{mmol})$ in THF $(70 \mathrm{~mL})$. At $-28^{\circ} \mathrm{C}$ the reaction mixture changed from yellow through green and finally became orange-brown. After crystallization from $\mathrm{MeOH}$ orange needles were obtained, $3.8 \mathrm{~g}, 10.3 \mathrm{mmol}$ (59\% yield). ${ }^{1} \mathrm{H}$ NMR $\left(\mathrm{CD}_{3} \mathrm{OD}\right): \delta 2.50\left(\mathrm{~s}, 3 \mathrm{H}, \mathrm{C}(\mathrm{O}) \mathrm{CH}_{3}\right), 2.67\left(\mathrm{~s}, 12 \mathrm{H}, \mathrm{NCH}_{3}\right), 3.77$ $\left(\mathrm{s}, 4 \mathrm{H}, \mathrm{ArCH}{ }_{2} \mathrm{~N}\right), 7.27(\mathrm{~s}, 2 \mathrm{H}, \mathrm{ArH}) .{ }^{13} \mathrm{C} \mathrm{NMR}\left(\mathrm{CD}_{3} \mathrm{OD}\right): \delta 26.62$ $\left(\mathrm{C}(\mathrm{O}) \mathrm{CH}_{3}\right), 51.90\left(\mathrm{NCH}_{3}\right), 73.80\left(\mathrm{ArCH}_{2} \mathrm{~N}\right), 119.94(\{\mathrm{Ar}\} \mathrm{CH})$, 
$136.21\left(\{\mathrm{Ar}\} \mathrm{CC}(\mathrm{O}) \mathrm{CH}_{3}\right), 148.62\left(\{\mathrm{Ar}\} \mathrm{CCH}_{2} \mathrm{~N}\right), 162.25(\{\mathrm{Ar}\} \mathrm{CNi})$ $200.58\left(\mathrm{C}(\mathrm{O}) \mathrm{CH}_{3}\right)$. FAB/MS $(\mathrm{m} / \mathrm{z}): 370\left(\mathrm{M}^{++}\right), 291\left(\mathrm{M}-\mathrm{Br}^{+}\right)$. Anal. Calcd for $\mathrm{C}_{14} \mathrm{H}_{21} \mathrm{BrN}_{2} \mathrm{ONi}$ : C, 45.21; $\mathrm{H}, 5.69 ; \mathrm{N}, 7.53$. Found: C, 45.06; H, 5.71; N, 7.46.

Cyclic Voltammetry. All experiments were performed in a glovebox, where a dry and oxygen-free nitrogen atmosphere was maintained. The measurements were made with a conventional three-electrode configuration with platinum working and auxiliary electrodes. Electrochemical studies were made in acetone and $\mathrm{CH}_{2} \mathrm{Cl}_{2}$ solutions. In acetone solutions an $\mathrm{Ag} / \mathrm{AgCl}(0.1 \mathrm{~mol}$ $\mathrm{dm}^{-3} \mathrm{LiCl}$ ) reference electrode was used; in $\mathrm{CH}_{2} \mathrm{Cl}_{2}$ solutions an $\mathrm{Ag} / \mathrm{AgI}\left(0.4 \mathrm{~mol} \mathrm{dm}^{-3} \mathrm{Bu}_{4} \mathrm{NClO}_{4}\right.$ and $\left.0.05 \mathrm{~mol} \mathrm{dm}^{-3} \mathrm{Bu}_{4} \mathrm{NI}\right)$ reference electrode was used. ${ }^{13}$ The reference electrodes were separated from the test solution by a glass frit and a Luggin capillary containing the supporting electrolyte $\left(0.1 \mathrm{~mol} \mathrm{dm}^{-3} \mathrm{Bu}_{4^{-}}\right.$
$\mathrm{NBr})$. In acetone $E_{1 / 2}$ for $\left(\mathrm{FeCp}_{2}{ }^{+} / \mathrm{FeCp}_{2}\right)=+0.63 \mathrm{~V}$ and in $\mathrm{CH}_{2} \mathrm{Cl}_{2} E_{1 / 2}$ for $\left(\mathrm{FeCp}_{2}{ }^{+} / \mathrm{FeCp}_{2}\right)=+0.87$ V.14 Maximum $i R$ compensation was applied. A PAR 273 potentiostat with PAR electrochemical analysis software was used. Cyclic voltammograms were obtained with a scan rate of $100 \mathrm{mV} \mathrm{s}^{-1}$. The recording device was a Kipp BD 30 recorder.

UV/Vis Measurements. UV/vis spectra were measured on a Varian Cary 1 instrument. The spectra of the organonickel(II) complexes $(2 \mathbf{a}-\mathbf{h})$ were measured under an argon atmosphere. For compound $2 \mathrm{a} U \mathrm{UV} / \mathrm{vis}$ spectra were also determined as a function of temperature and in a series of solvents to gain insight into possible solvatochromism of the absorption bands.

OM930615N 